\title{
Japanese ‘Right-wing Rock'? A Lyrics Content Analysis
}

\author{
Stefan Fuchs
}

\begin{abstract}
So far largely unnoticed, a right-wing extremist current within the rock music oriented subculture of Japan can be observed. This subcultural phenomenon bears resemblance in appearance to a phenomenon that is commonly referred to as 'right-wing rock' (Rechtsrock) in German-speaking countries. On the basis of a substantial compilation of relevant lyrics, the present paper seeks to examine whether this resemblance can also be located in terms of the ideological contents. Focussing on the linguistic inventory of the sample of lyrics, how a particular vocabulary is used to construct a collective identity and to convey a range of rightist topics will be examined. It will be shown that various terms that are frequently used in the analysed lyrics contain references to nationalistic and/or militaristic thought. Some lyrics propagate historical revisionist or negationist views on history and on the whole the analysed lyrics glorify martial concepts of maleness. The analysis thus justifies the conclusion that the musical phenomenon in question can be defined as a Japanese form of right-wing rock.
\end{abstract}

Keywords: Japanese popular culture, right-wing extremism, rock music, masculinities

D1ae Fuchs, Stefan. "Japanese 'Right-wing Rock'? A Lyrics Content Analysis." In Vienna Journal of East Asian Studies, Volume 6, eds. Rudiger Frank, Ina Hein, Lukas Pokorny and Agnes Schick-Chen. Vienna: Praesens Verlag, 2014, pp. SenS 75-124. https:/doi.org/10.2478/vjeas-2014-0009 


\section{Introduction}

By the end of the 1970s in Britain, an ideological shift had become evident within parts of the rock music-oriented subculture. Mainly within the punk and skinhead subcultures several bands put forward lyrics containing glorification of violence, xenophobic or racist thoughts, and, in some cases, genuine admiration for fascist ideologies - topics that until then had been absent in rock music, ${ }^{1}$ which, in the aftermath of the hippie and the student movements, generally had been considered to be a conciliatory style of music. Undoubtedly, who was most prominent in this new reactionary current within rock music was the English band Skrewdriver, whose founder and vocalist Ian Stuart Donaldson (1957-93) played a crucial role in shaping the musical style, as well as the ideological character, of what would soon become the right-wing extremist faction of the skinhead subculture (Farin 1997: 214-217). By the early 1980s, Skrewdriver had created a raw style of punk rock characterised by a violent imagery and lyrics that convey racist and white supremacist thought and refer to the ideology of National Socialism. Popular within certain spheres of the rock music-oriented subculture and fuelled by growing antiimmigrant sentiments, an array of bands similar to Skrewdriver appeared, first in the United Kingdom (UK), and soon after in most countries of the European West, in North America and Australia, in several South American and later also in some Eastern European countries. In Germany, this phenomenon came to attract significant attention by parts of the mass media in the early 1990s, when in the wake of the German reunification a series of pogrom-like xenophobic riots occurred (Farin 1995: 6). Primarily owing to the German tabloid press, the resulting discourse was dominated by a preoccupation with alleged brutalisation of youth culture. Relying on catchwords like 'youth violence' and 'extremism', the violent surge of a xenophobic and racist social climate was primarily ascribed to marginal groups within youth subculture (Häusler 2002: 263-264). In particular, the conspicuous presence of skinheads at neo-Nazi rallies substantiated suspicion that the right-wing extremist attitudes and violent behaviour in some youths had to be explained for the main part by the fomenting effects of a certain type of rock music. To denominate this type of rock music, the term 'Rechtsrock' was coined; a term that found its way into common language in German-speaking countries and that can be roughly translated as

1 Although widely regarded as the first time that racist ideas emerged in modern popular music, Michael Wade posits that the roots of this development can be traced back to the southern United States of the 1960 s, when, in the advent of desegregation, various heavily racist songs were recorded by the country musician Johnny Rebel (2007). 
'right-wing rock'. ${ }^{2}$ Although there are terms like 'Rock Against Communism, 3 (RAC) or the French equivalent 'Rock identitaire français' ${ }^{4}$ (RIF) used by rightwing extremist subculture members themselves to refer to this type of music, outside the German-speaking region there is probably no term like 'Rechtsrock' that found its way into general language use. Furthermore, chances are that the term 'Rechtsrock' reflects a perception of the musical phenomenon that is specific to the German-speaking region - a perception that to some extent is rooted in the region's approach to its own history.

Although so far largely unnoticed, ${ }^{5}$ a current that bears a strong resemblance in appearance to the type of rock music described above can also be found within the rock music-oriented subculture of Japan. A number of Japanese bands have adopted the style and sound pattern of mainly British bands of the right-wing extremist subculture and have blended it with Japanese nationalistic symbolism. On the basis of a substantial compilation of lyrics of relevant bands, the present discussion strives to clarify if this striking resemblance can also be located in terms of the ideological contents. Using the method of lyrics content analysis, I will examine whether this musical phenomenon can be defined as a Japanese form of right-wing rock. In doing so, I will deliberate to what extent the concept of right-wing rock can be applied to comparable phenomena outside the German-speaking region.

This paper is divided into four sections: beginning with an approximate definition of right-wing extremism and conservatism, followed by an overview of the textual specifics of right-wing rock, the core of the present enquiry is a lyrics content analysis carried out in two steps. The first is an analysis of the ideo-linguistic inventory of the lyrics. On the basis of a word count, the essential aspects of the terminology of the music in question are determined. Exemplified by quotations from the analysed lyrics, it will be shown how a particular vocabulary is used to construct a nationally and/or racially defined collective identity. Furthermore, the section about the vocabulary discusses various forms of agitation that come up in the analysed lyrics. Using the symbol of the cherry blossom as an example, an analysis of the historical references that can be found in the lyrics will be conducted. In the second

2 Following the example of Wade (2007), the loan translation 'right-wing rock' is used in this paper.

3 The term 'Rock Against Communism' dates back to a rock festival, which was held for the first time in Leeds in 1979, supported by the right-wing extremist party the British National Front. The festival originated as a backlash against the campaign 'Rock Against Racism', which had been initiated before by several popular musicians (Sabin 1999: 207-208).

4 Originally the title of a various artist compilation, 'rock identitaire français' (French identitarian rock) nowadays signifies a right-wing extremist tendency within French rock music (Lowles 2002: 238).

5 To date, probably the only other academic discussion of this type of Japanese rock music is the M.A. thesis of the anthropologist Takaizumi Taku 高泉拓, which was also published in a journal. Takaizumi refers to this phenomenon as uyoku-rokku 右翼ロック; a compound of the two words 'uyoku' (right-wing) and 'rokku' (rock music) (2005). Asked about the source of this denomination, Takaizumi responded (by e-mail on 27 November 2011) that he had adopted it from a magazine that he could not recall. 
step, two particular themes and topical elements of the lyrics are discussed in greater detail: for one, the way the examined lyrics deal with Japan's wartime past will be presented. For the other, concepts of violence and maleness that are conveyed in the analysed lyrics will be discussed. These two steps of the content analysis lead up to the fourth section, which delivers a concluding assessment of the phenomenon in question.

\section{Preliminaries: Rightist ideologies and right-wing rock}

When speaking about the emergence of a political current within contemporary popular culture, it is necessary to specify a few terms that are of importance for the subject of enquiry. As the term 'right-wing rock' is based on the proposition that the two antipodal terms 'left' and 'right' can serve as a means to evaluate political phenomena, some of the fundamental characteristics of rightist ideologies shall be discussed below. In this respect the characteristics of right-wing extremism are of particular relevance since right-wing rock is usually seen as a popular cultural or countercultural expression of right-wing extremism. Some of the attitudes that are expressed in the lyrics analysed can probably not be grasped entirely without some previous information about the specifics of right-wing extremism in Japan. Therefore, such an overview shall be added to the general definition of the characteristics of right-wing extremism. Furthermore, a delineation of the type of rock music that the present discussion relates to will be given by introducing the ideological qualities that constitute right-wing rock.

\section{Localising right-wing extremism}

So far there is no academic consensus on the comprehension of right-wing extremism, which for the main part is due to the fact that right-wing extremism cannot be grasped as a single ideological system. Taking into account the plethora of different ideologies and sometimes diverging aims of right-wing extremist parties, organisations, or individuals, it has to be conceived as a complex phenomenon. The following definition cannot make allowance for this complexity, but rather serves as a specification of the comprehension of right-wing extremism that the subsequent discussion of song lyrics is based on.

A common ground of rightist ideologies can be found in what Oliver H. Woshinsky describes as the idea of 'justifiable inequalities' (2008: 150). According to Woshinsky, in the eyes of rightists, the leftist notion of equal relationships between humans makes no sense. They argue that some people $d o$ deserve more than others-either because they work harder and contribute more to society or because they 
are superior people. In this respect, rightist ideologies differ among themselves mainly in terms of the grounds on which they maintain the idea of inequality. Conservatism justifies inequality by stressing the notion of diligence and sloth, i.e. the conviction that through effort anyone can gain wealth and power and the majority of those who do not are not ambitious enough (ibid.: 150-152). Right-wing extremist concepts of inequality, in contrast, are first and foremost based on the idea of the superiority of certain innate qualities that only a small proportion of humankind possesses (ibid.: 154).

Stefan von Hoyningen-Huene states that in the context of right-wing extremism, inequality has to be understood in terms of 'not of equal worthiness', which becomes manifest in beliefs such as racism or ethnocentrism. These beliefs may go along with ideas of social Darwinism, i.e. convictions that the stronger or better will prevail, whereas at a larger scale these ideas sometimes dominate the way in which relationships between nations or peoples are perceived (von Hoyningen-Huene 2003: 27-28). Nationalism, the construct of definitively separated nations, is a fundamental element of right-wing extremist ideologies, which may involve the aggrandisement of one's own nation. Within national borders, nationalist thought in many cases leads to the denial of the existence of individual interest, while the idea of national coherence comes to the fore. Utilising the argument that the members of a nation intrinsically share the same interests, sometimes democracy is displaced by an authoritarian form of government (ibid.: 28).

One prominent feature of right-wing extremist ideologies is a particular approach to history that tends to romanticise the pre-industrial age but rejects the social developments of modern history such as pluralism, individualism, liberalism, or emancipatory ideas (Bergmann 1994: 189). One characteristic of right-wing extremist approaches to history is the preoccupation with topics related to war, whereas one's own nation's involvement into wars is often glorified or trivialised by right-wing extremists, who oftentimes hold a disposition for revisionist thoughts (von Hoyningen-Huene 2003: 28). Moreover, right-wing extremism features a certain stance on violence that is reflected in a demand for violence on the part of executive authority, the general approval of violence as a means to resolve conflict, and sometimes also personal willingness to resort to violence (ibid.).

Right-wing extremist thought may consist of one or more of the elements mentioned above, but it does not necessarily include all of them. Ideas of inequality in connection with the affirmation of violence are often cited as the main features of right-wing extremism. Nationalistic or chauvinistic attitudes embody popular aspects of right-wing thoughts. However, in some cases right-wing extremism cannot solely be determined by thoughts of inequality, nationalistic ideas, or the approval of violence. With regard to the present discussion it seems appropriate to apply a broader definition of right-wing extremism, since some of the bands examined do not display glorification of or calls for violence, but still can be defined as right- 
wing extremist by the authoritarian or revisionist attitudes they hold. What can be revealed in advance is that the lyrics of only a few bands suggest a clear-cut rightwing extremist conviction, whereas the majority of the bands convey messages that indicate a rather vague right-wing extremist position. Furthermore, the boundary between conservatism and right-wing extremism is sometimes not clear. The lyrics examined do not solely contain arguments that should be assigned to the far-right section of the political spectrum, but rather can also be found in more moderate conservative spheres of public discourse.

\section{Japanese right-wing extremism}

It is safe to assume that the ideological elements specified above are also the basis of Japanese right-wing extremism. One fundamental specific of Japanese right-wing extremism is the belief that the Japanese Imperial Family is of divine descent. This particular world view is for the main part derived from the mythological accounts of the Kojiki 古事記 and the Nihonshoki 日本書紀 (or Nihongi 日本紀), two early 8thcentury chronicles that describe Japan as a unique land of gods and depict the legendary first emperor, Jinmu-Tennō 神武天皇, and indirectly also his subjects, i.e. the Japanese people, as descendants of the sun goddess Amaterasu 天照 (Antoni 1998: 34-35; Nawrocki 1998: 21-22). The conviction that the inviolability of imperial holiness provides the basis for the Japanese nation can be viewed as the common ground of the various right-wing extremist factions of Japan.

Post-war Japanese right-wing extremist tendencies were significantly influenced by the Japan-United States (US) relationship, an issue that is also of importance regarding some of the lyrics examined. The majority of right-wing extremist organisations that formed during the post-war period saw themselves as allies of the US, bonded by the common intention to combat communism and Japan's geographical proximity to the former Soviet Union and the People's Republic of China. According to a publication of the Uyoku-mondai kenkyū-kai 右翼問題研究会 (Research Society on Right-wing Extremism), nowadays these factions - which in Japanese are commonly summarised as shinbei-hankyo 親米反共 (pro-American and anticommunist) - advocate the continuation of the US-Japan Security Treaty ${ }^{6}$ but call

6 Signed in 1960, the US-Japan Security Treaty schedules a close collaboration in regard to Japan's national defence. The treaty implied the permanent presence of US troops in Japan, which caused long-lasting protests in Japan. 
for the revision of the Japanese Constitution, ${ }^{7}$ which they regard as imposed upon the Japanese people by the occupation forces (Uyoku-mondai kenkyū-kai 2006: 111).

In response to the protest movement against the US-Japan Security Treaty, which was carried out predominantly by left-wing student associations, in the early 1960s Japan saw the arrival of an academic far-right movement that followers refer to as Minzoku-ha 民族派 (ethnic faction) but is usually known to the general public by the name Shin-uyoku 新右翼 (The New Right), a label coined by the Japanese mass media as an equivalent to the so-called Shin-sayoku 新左翼 (The New Left). ${ }^{8}$ This new far-right camp criticised the notion of anti-communism as overstated within the Japanese right-wing and instead put forward the idea of a national revolution. At the same time, the New Right tended to be rather dissident and opposed the (political) establishment (ibid.: 112-113). The break away from the pro-American far-right induced the diversification of the right-wing extremist spectrum. Currently the socalled New Right incorporates a plurality of different factions that distinguish themselves for the most part by anti-American attitudes and are to some extent critical of capitalism. They tend to comment on current affairs and in doing so try to influence public discourse.

\section{Right-wing rock}

As indicated at the beginning of the present paper, the term 'right-wing rock' has to be understood to some extent as the product of a short-term media-hype. Thus, it has to be taken into account that the term does not originate from a sober-minded discourse. Nevertheless, the term 'right-wing rock', unlike other denominations such as the rather euphemistic 'Rock Against Communism', seems to be most appropriate for the discussion of the present musical phenomenon. That is to say that besides a distinctive style of music, the term 'right-wing rock' comprises a particular range of ideological contents and topical elements. This assumption may still require in-depth transnational analysis, but regardless of certain particularities that stem from the respective regional, historical, or cultural background, right-wing rock implies a range of common lyrical features that can arguably be determined by the following: ${ }^{9}$

7 The Japanese Constitution came into force in 1947 and has never been changed since. Because it was written under the supervision of the occupation forces, the Japanese right-wingers in particular argue that the Constitution was inflicted upon Japan by those who emerged victorious from World War II, and it should therefore be either radically revised or invalidated altogether. In this regard, especially Article Nine of the Constitution, by which Japan renounced belligerence and agreed not to maintain armed forces, has repeatedly been criticised as the outcome of 'victor's justice'.

8 The Japanese New Left came into being in the late 1950s, when parts of the various left-wing student associations broke away from the Japanese Communist Party (Hasegawa 2003).

9 This specification of the topical characteristics of right-wing rock is based on two analyses of German lyrics (Farin 1999; Flad 2002), an analysis of Swedish, British, and American lyrics (Lööw 1998), and an analysis of British and American lyrics (Cotter 2004). 
- One vital element of right-wing rock is the idea of nation, which, for instance, is reflected in the worship of national symbols, the propagation of national myths, or the self-identification with archaic cultures or peoples. In the context of right-wing rock, the term 'nation' is usually closely connected to ideas of race or culture.

- Right-wing rock aims at constructing and maintaining collective identities, usually by utilising the idea of a cohesive in-group that is often delineated as the vanguard of a national movement.

- This elitist notion of in-group solidarity is often based on the demarcation against 'the Other', which usually results in hostility. In this respect right-wing rock tends to condemn disadvantaged groups, which is often reflected in xenophobic, racist, or sometimes homophobic lyrics.

- Lyrics of right-wing rock sometimes contain glorification of violence, and violence is largely praised as a means to resolve conflict. This may present itself in overt advocation of the rule of force but sometimes involves more subtle approvals of violence. What is noteworthy in this regard is the overwhelmingly positive interpretation of war. War is depicted as a desirable impetus for technical as well as social progress.

- In addition, ideas of violence and war are the defining factors in the conception of masculinity represented in the lyrics of right-wing rock. Masculinity is associated with attributes such as honour, pride, or vigour. Women, however, are nearly absent in right-wing rock. Merely a few female musicians take part in the scene, and women are scarcely represented in the lyrics of right-wing rock. ${ }^{10}$

- Moreover, right-wing rock is characterised by anti-modernism. While social ideas of modern history are dismissed as moral degenerations, certain eras of the past are glorified. Especially National Socialism or similar authoritarian or militaristic forms of government, but sometimes also pre-modern eras, are used as guidelines for social or governmental utopias.

10 For information on the situation of women in German right-wing rock, see Döhring and Feldmann 2002. An exception to the marginal presence of women in right-wing rock is the Swedish singer Saga, who shot to fame in the far-right music scene in the 2000s (Shekhovtsov 2013: 277). 


\section{The sample of lyrics}

The sample of lyrics that form the basis of the present lyrical content analysis was compiled in the course of approximately five years. During that time the majority of relevant lyrics could be gathered mainly because the musical phenomenon in question can be found within relatively limited spheres of Japanese rock music-oriented subculture. Many of the bands examined in the present discussion frequently play concerts together, and their music appeals to similar audiences. Besides being recognisable in most cases by a self-representation that is modelled on Western right-wing rock bands, these bands, as will be shown, share a distinctive vocabulary that is sometimes also reflected in the titles of their albums.

In order to allow for linguistic comparability, the examined sample of lyrics is exclusively compiled of lyrics written, for the main part, in Japanese. Even though a few bands, such as Gruesome or Ikazuchi 雷 may be representative for the present phenomenon, they are unaccounted for in the following analysis because their lyrics are written in English. Another decisive choice for the compilation process of the sample was the aim to include many different bands. In doing so, a sample of 180 lyrics by 25 bands or interpreters was compiled, using 37 sound carriers that were published between 1988 and 2010. ${ }^{11}$ This may not allow a complete examination of the musical phenomenon in question, but still a substantial one.

\section{Lyrical content analysis through a word count}

While translating the lyrics, it gradually became evident that they feature a largely similar vocabulary that serves as a basis for a certain range of topics. The upcoming discussion is to show that it is precisely this common word choice, as well as the focus on particular topics, that integrates the examined bands as a subcultural entity in the sense of right-wing rock. As the first step of the lyrical content analysis, on the basis of a word count, important key words and other terms frequently mentioned in the sample of lyrics are determined. A selection of these terms is displayed in Table 1 below. Regarding the method of the word count it should be noted that the analysis includes mainly words that consist of a single Chinese character. In the case of words that consist of two or more Chinese characters the Chinese characters are assigned to the respective term. That is to say that for instance in the case of the noun tōshi 闘志 (will to fight) the two components tatakai 闘 (fight) and kokorozashi 志 (will) are assigned to the corresponding term. Such compounds are listed in the right column of Table 1.

11 For a list of the music used in the analysis see the Discography at the end of the paper. 
Table 1

\begin{tabular}{|c|c|c|}
\hline English meaning & Japanese term & $\begin{array}{l}\text { Number of mentions/ } \\
\text { compounds }\end{array}$ \\
\hline I/we/mine/our & $\begin{array}{l}\text { ware 我/warera 我ら or 我等 } \\
\text { /waga 我が }\end{array}$ & $\begin{array}{l}208 \\
\text { thereof } 80 \text { waga (mine/our) } \\
\text { thereof } 73 \text { warera }\end{array}$ \\
\hline country/state/nation & kuni 国 & $\begin{array}{l}201 \\
\text { thereof } 73 \text { sokoku } \text { 祖国 } \\
\text { (fatherland) }\end{array}$ \\
\hline heart/mind & kokoro 心 & 168 \\
\hline soul/spirit & tamashii 魂 & $\begin{array}{l}132 \\
\text { thereof } 18 \text { yamatodamashii } \\
\text { 大和魂 } \\
\text { (the Japanese spirit) }\end{array}$ \\
\hline blood & chi 血 & $\begin{array}{l}105 \\
\text { thereof } 35 \text { chishio 血潮/血. } \\
\text { 汐 } \\
\text { (bloodstream) }\end{array}$ \\
\hline Japan & Nihon/Nippon 日本 & 102 \\
\hline fight/to fight & $\begin{array}{l}\text { tatakai 闘い/戦い } \\
\text { tatakau } \text { 闘う/戦う }\end{array}$ & $\begin{array}{l}100 \\
\text { thereof } 12 \text { tōshi 闘志 (will } \\
\text { to fight) } \\
\text { thereof } 5 \text { hansen 反戦 } \\
\text { (pacifism) } \\
\text { thereof } 7 \text { senjo 戦場 } \\
\text { (battlefield) } \\
\text { thereof } 5 \text { senshi 戦士 } \\
\text { (warrior) }\end{array}$ \\
\hline flower/blossom & hana 花/華 & 87 \\
\hline pride/to be proud & hokori 誇り/誇る & $\begin{array}{l}86 \\
\text { thereof } 2 \text { puraido プライ } \\
\text { ド (pride) } \\
\text { thereof } 2 \text { kyojji 㐨持 (pride) }\end{array}$ \\
\hline wind & kaze 風 & $\begin{array}{l}74 \\
\text { thereof } 3 \text { kamikaze 神風 } \\
\text { (divine wind) }\end{array}$ \\
\hline to burn/to set fire to & moeru 燃える/moyasu 燃やす & 69 \\
\hline they/the others & yatsura 奴ら & 64 \\
\hline to fall/to die (off) & chiru 散る & 63 \\
\hline $\begin{array}{l}\text { to rise/to stand up; } \\
\text { to resist/to fight against }\end{array}$ & $\begin{array}{l}\text { tachiagaru 立ち上がる } \\
\text { tachimukau 立ち向かう }\end{array}$ & 61 \\
\hline will & kokorozashi 志 & 59 \\
\hline $\begin{array}{l}\text { to protect/to defend; } \\
\text { to protect to the end }\end{array}$ & $\begin{array}{l}\text { mamoru 守る/護る } \\
\text { mamorinuku 守り抜く/護り抜く }\end{array}$ & 52 \\
\hline
\end{tabular}




\begin{tabular}{|c|c|c|}
\hline love & $a i$ 愛 & $\begin{array}{l}48 \\
\text { thereof } 9 \text { aikoku 愛国 } \\
\text { (patriotism) }\end{array}$ \\
\hline darkness & yami 闇 & 41 \\
\hline $\begin{array}{l}\text { to wake up/ } \\
\text { to come to one's senses }\end{array}$ & me o sameru 目を覚める/醒める & 34 \\
\hline to restore/to regain & torimodosu 取り戻す & 30 \\
\hline peace & heiwa 平和 & 29 \\
\hline freedom & jiyzu 自由 & 29 \\
\hline eternity/eternal & eien 永遠/towa 永久 & 29 \\
\hline cherry blossom/cherry tree & sakura 桜/櫻 & 21 \\
\hline Hinomaru (the Japanese flag) & Hinomaru 日の丸 & 18 \\
\hline truth & shinjitsu 真実 & 18 \\
\hline $\begin{array}{l}\text { deceit/scam/sham; } \\
\text { to deceit/to cheat/to dupe }\end{array}$ & $\begin{array}{l}\text { itsuwari 偽り } \\
\text { itsuwaru 偽る }\end{array}$ & $\begin{array}{l}17 \\
\text { thereof } 17 \text { gizen 偽善 } \\
\text { (hypocrisy) } \\
\text { thereof } 2 \text { nise no 偽の } \\
\text { (fake) }\end{array}$ \\
\hline people/race/ethnicity/nation & minzoku 民族 & 17 \\
\hline rule/control/power & shihai 支配 & 14 \\
\hline (United States of) America & Amerikaアメリカ & $\begin{array}{l}13 \\
\text { thereof } 1 \text { beikoku 米国 } \\
\text { (America) }\end{array}$ \\
\hline tradition & dentō伝統 & 12 \\
\hline oath/to pledge & chikai 誓/chikau 誓う & 10 \\
\hline (political) restoration & ishin 維新 & 7 \\
\hline spirits of the war heros & eirei 英霊 & 5 \\
\hline hero & $e i y \bar{u}$ 英雄 & 5 \\
\hline traitor to the nation & baikokudo 売国奴/kokuzoku 国賊 & 4 \\
\hline loyalty & chūgi 忠義 & 3 \\
\hline
\end{tabular}

\section{The linguistic properties of the lyrics}

In the following section, the use of vocabulary within the lyrics will be discussed by utilising some of the terms determined in the word count. Exemplified by quotations that illustrate the specific connotations of frequently used terms, the ideo-linguistic contents of this type of rock music will be analysed.

The polarisation of in-group and out-group: Warera and yatsura

The Japanese personal pronoun 'ware' 我 (I) is the word most frequently used in the sample of lyrics, including the possessive pronoun 'waga' 我が (mine/our) and the personal pronoun 'warera' 我ら/我等 (we). Such frequent use of the various forms of 'ware' indicates a high degree of self-centredness since unlike English grammar 
that usually requires a subject to form a sentence, in Japanese the subject is often omitted. The self-centredness of the examined type of rock music is also reflected in the emphasis on the idea of an in-group. This in-group (usually 'warera') is, however, in most cases only vaguely outlined, i.e. it is not clear whom it involves. This somewhat open constitution of the in-group may facilitate the creation of a feeling of belonging among broader parts of the audience. Nevertheless, as will become clear, the in-group is mainly limited to people of Japanese descent who embody what is regarded as the 'right spirit'. Furthermore, the in-group is usually portrayed as an exclusively male brigade that is characterised by callousness and readiness to combat. Thus qualities are attributed to the in-group that, following the inner logic of the lyrics, can be perceived as outstanding, which makes affiliation something special. Apart from being based on such positive portrayals of one's own collective, the conception of the in-group is often constructed against non-members, i.e. the outgroup. In this case the delineation of the in-group (warera) rests on the demarcation against the out-group usually referred to as 'yatsura' 奴 $ら$ (slightly derogative for 'they' or 'the others'). This antagonistic conception of 'we' against 'them' is a determinative element throughout the sample of lyrics and is for example expressed as follows:

Can't you hear their laughter, loud as if it could silence our song [...] (Strong Style 2001: "Sennō" 洗脳 [Brainwash]). ${ }^{12}$

Interestingly enough, with the exception of a few lyrics that involve explicit concepts of the in-group's enemies, the out-group (yatsura) is outlined as vaguely as the in-group (warera). The notion of 'them' is first and foremost based on 'others that do not belong to us'. In this regard the lyrics are to a certain degree open to the individual interpretations of the listener and may serve as an outlet for personal animosities. Having said this, it must be noted that not any random subject can be assigned to the out-group as the following lyrics show:

The red-hot Hinomaru we take into our hearts/ The burning spirit here and now/ We believe only in victory/ Punch their teeth in with your fist of anger/ Stand your ground on the windswept soil/ Run on with your blood-splattered fist to the never-ending battle/ 'til victory is in your hands/ Once again the spirit flames up as you confront your next enemy/ Like the burning sun/ Like a blood-thirsty beast [...] (Raiya 雷矢 2005: “Owari naki tatakai”終わりなき戦い [The Never-ending Battle]).

12 All quotations of lyrics were translated by the author. Moreover, the citations of song lyrics are treated like citations from literary sources. The parentheses following each song lyric citation contain the band name, the year of release, and the song title, followed by the translation of the song title in brackets. In the discography at the end of this paper a list of all records used for the analysis can be found. However, the song titles are not listed separately, but the record containing the respective song can be found by the year of release. 
What can be deduced from this passage, although it is up to the listener to decide who the enemy is, is that the out-group is at least vaguely defined since those who take the Hinomaru (the Japanese flag) into their hearts and believe in victory are contrasted against those who get their teeth punched in. By setting apart the in-group through the motive of national pride these lyrics gain an ideological importance that exceeds mere indulgence in fantasies of violence.

Another way of integrating the listeners into the in-group is to directly address them. Using either the colloquial, but sometimes derogative personal pronoun, ' $O$ mae' お前 (you) or the, in modern language use, rather rough 'kisama' 貴様 (you) in many lyrics suggests to the listener that he or she has a common interest with the in-group. Consequently the second person singular is also defined in contrast to the others (yatsura):

Brainwash! You are not yourself anymore/ Everything goes as they planned/ Can't you see the black shadows of those who take control of the world/ Their evil eyes are watching you [...] (Strong Style 2001: "Sennō").

\section{One heart, one soul: Kokoro and tamashii}

Contrary to what one might expect, the examined type of rock music is characterised not only by depictions of relentless, hard-boiled manhood, but sometimes also by romanticism. Of particular note in this regard are the two terms 'kokoro' 心 (heart/mind/spirit) and 'tamashii' 魂 (soul/spirit). According to Klaus Antoni, in most cases 'kokoro' means 'heart' in a metaphorical rather than a biological sense (2004). Rather than the actual organ, which in Japanese is usually referred to by the medical term 'shinzō' 心臓, 'kokoro' bears the meaning of 'heart' in spiritual or psychological terms. Although in the examined lyrics the terms 'kokoro' and 'tamashii' are often used synonymously, 'kokoro' is imagined as intrinsically connected to the human body. Often the heart (kokoro) is portrayed as a force that overrides the human consciousness and is seen as the cause for actions that the lyrical subject perceives as outside of its control. That is to say that individual as well as collective actions in many cases are motivated not by external circumstances, but rather by a 'call from the heart'. As reflected in the following lyrics, the heart (kokoro) is often viewed as the only source of earnest convictions:

These days everyone is chasing wealth/ Have you people already forgotten the important things in life?/ True wealth lies within the heart/ The courage to live one's life sincerelythat's righteousness [...] (Strong Style 2001: “Seigi” 正義 [Righteousness]).

Another term that is central to the vocabulary of the analysed lyrics is 'tamashii', which can be translated as 'soul' or 'spirit'. This term is generally used in a similar context as 'heart' (kokoro) but tends to transcend the sphere of the individual. 
Initially meaning a soul inherent in living things, in the lyrics tamashii is portrayed as a spiritual entity that simultaneously rests within the individual and the collective. Through the innate soul the individual is inescapably tied to a greater spiritual collective that is usually defined as the 'Japanese soul' or the 'Japanese spirit' (yamatodamashii 大和魂, a term that shall be discussed shortly). The use of the terms 'heart' (kokoro) and 'soul' (tamashii) reflects the idea that both should be of an original, un-depraved condition:

Your heart is clear/ Unleash your vitality/ Polish your innocent heart $/{ }^{13}$ Your heart is calm/ Unleash your vitality/ Polish your innocent heart/ Now!/ Swear to go our way until your life is over/ Set fire to your chest/ The truth lies within the heart [...] (Resolute Immortal Partizan 2002: “Kokoro moyu” 心燃ゆ [Burning Heart]).

The topos of bodily fire that comes up in the above quotation (set fire to your chest) and is also reflected in the title of the song is frequently mentioned along with the idea of the 'heart' and the 'soul'. This becomes manifest in the often used lofty expression 'tamashii o moyasu' 魂を燃や寸(to inflame the soul/the spirit), which normally appears in imperative form as the following examples demonstrate:

Don't surrender to their raging madness/ Inflame the unrelenting spirit/ Create your strongest selves on this wide soil [...] (Strong Style 2001: “Sokoku no tame ni” 祖国のた めに [For Our Fatherland]).

Keep on fanning the flames of the spirit/ Let our national flag wave over your heads [...] (Bull the Buffalos ${ }^{14}$ 1993: "Bull the Buffalos").

In addition, it can be noted that terms related to fire usually have a positive connotation throughout the sample of lyrics. Fire is represented as a salutary, cathartic element and sometimes also acts as a metaphor for Japan, the 'land of fire'. This metaphor can be found for instance in a song by the band Strong Style titled "Hi no kuni” 火の国 (The Land of Fire), which may allude to the volcanism of Japan. In this song, a mystical power inherent to Japan that eliminates all kinds of evil is evoked, which makes it worth quoting at length:

Our accursed enemies are the drug dealers/ Controlled by the devil they seduce children/ Their black bellies are swelling while the children lose the purity of their eyes/ Moneycrazed the people lose sight of the heart/ Although already drowning in wealth, they keep

13 It is not clear, and to some extent open to individual interpretation, if there is another, more metaphysical dimension to this verse. What is translated here as 'innocent heart' (mushin no kokoro 無心の心) might also refer to the Zen Buddhist concept of mushin 無心 that is often translated as 'no-mind' (or 'nomindedness') and that broadly speaking describes a transethical state of mind that is free from discrimination (Döll 2010: 84-85).

14 Since there was no lyrics sheet available, all lyrics of the band Bull the Buffalos were gathered by listening. Although this was done very carefully in co-operation with a Japanese native speaker, mistakes cannot be ruled out entirely. 
[hoarding] on and on/ We must not leave our future to devils masked as humans/ Don't overlook their evil deeds!/ Don't lose sight of our enemies!/ Yamato! Land of fire! Keep on burning for all eternity/ Burn to nothing all that is depraved (Strong Style 2001: "Hi no kuni").

The term 'Yamato' 大和, which is used as a name for Japan in the above lyrics, leads to another essential term of the type of rock music under consideration: 'yamatodamashii', the 'Japanese soul' or the 'Japanese spirit', reflects the idea of a spiritual entity that transcends the individual to an even stronger degree than 'heart' (kokoro) or 'soul' (tamashii). Often cited by the Japanese far-right, the term 'yamatodamashii' expresses the notion that the Japanese people share a specific selfcontained national spirit, which can arguably be compared to the German Romantic idea of 'Volksgeist'.

The component 'yamato' dates back to the Yamato Kingdom that in the 3rd century AD, from an area located in today's Nara prefecture, expanded to large parts of the Japanese archipelago as well as parts of the Korean peninsula (Brown 1993: 108144). John W. Dower states that in the context of the word composition 'yamatodamashii', the term 'yamato' has to be seen in connection with a particular mythological world view, since national myths name Yamato as the place where in $660 \mathrm{BC}$ the alleged first emperor, Jinmu-Tennō, founded the imperial line (2002: 317). Saitō Shōji 斎藤正二, who examines the idea of 'yamatodamashii' from a historical perspective, points out that since 1945 the concept has been mostly associated with ideas of Japanese expansionist militarism (1972: 3-4). However, it can be traced back to the Heian period (784-1185 AD), when 'yamatodamashii' had an entirely different meaning and was used to describe feminine or peaceful traits. The fact that ideas of belligerence adhere to the modern conception of 'yamatodamashii' is mainly due to its reinterpretation by thinkers of the kokugaku 国学 (national studies) who, from the late 18th century onwards, studied the remains of classical Japanese literature and blended the term with militaristic thought (ibid.: 4). Nishikawa Yoshimitsu 西川吉光 notes that it was especially around the First Sino-Japanese War (1894-95) that 'yamatodamashii' was propagated in terms of a soldierly spirit (2010: 5). This militant conception of the term played a significant role in Japanese propaganda during the Pacific War (1941-45) — which is probably the reason why the term is still present in today's nationalistic rhetoric - and served as a basis of the doctrine that Japan will win the war through spiritual superiority. In the examined lyrics yamatodamashii is often portrayed as the ethos of the forefathers and comes up primarily where the necessity of a return to lost values is claimed:

Where did the magnificent Japanese spirit go that made us fight the abominable great 
powers of the whites?! [...] (Ishinsekiseijuku ${ }^{15}$ 維新赤誠塾 1999: “Mukokusekiyarō” 無 国籍野郎 [Multicultural Bastards]).

The urge to fight is portrayed as the essence of Japanese nature, and the Japanese invasion of Asia, as well as the Pacific War, is glorified as a rebellion against Western powers (an often used topic that will be discussed in further detail below). Other lyrics that worship fallen Japanese soldiers suggest that the self-sacrifice of the war generation obliges the people of today to be loyal towards yamatodamashii:

You let your stormy lives blossom and then you fell/ That comrade/ That voice/ That back/ That hand/ Oh proud Japanese spirit!/ For you our blood is burning [...] (Resolute Immortal Partizan 2001: “Keppū” 血風 [Bloodshed]).

Bringing the above examinations to a conclusion, it can be asserted that the two terms 'kokoro' (heart) and 'tamashii' (soul) serve as means to convey ideologically loaded messages. The listener is not addressed by bringing forward arguments, but is rather subliminally urged on an emotional basis to identify with the in-group. The in-group is first and foremost defined by a common 'soul' or 'spirit' that sets it apart from the others (yatsura). What is important in this regard is that the soul is conceptualised as simultaneously metaphysical and carnal. In the lyrics the display of ideas is usually accompanied by impetuous bodily processes, and human thinking is described as regulated by the body. Thus the mind is subordinate to the body. Moreover kokoro and tamashii are sometimes portrayed as irrepressible forces that take control of their bearer. Therefore, individual as well as collective convictions do not result from autonomous opinion formation but are innate qualities. Likewise, the historically loaded term 'yamatodamashii' is used to suggest that the body of thought presented in the lyrics is inherent in members of the Japanese people. Accordingly, those who contravene the Japanese soul wage a futile struggle against their own nature. Sometimes the proposal to identify with yamatodamashii is linked to threats, since those who act in opposition to their alleged Japanese nature are regarded as members of the others (yatsura), who are often threatened. In this connection the others are for instance described as 'soulless' (tamashii naki 魂なき):

15 Although among the bands examined Ishinsekiseijuku is probably the best known, it is also the most atypical. Ishinsekiseijuku play punk rock that conveys right-wing extremist ideas, but unlike the majority of the other examined bands their musical style and self-representation does not resemble British models of right-wing rock. Following the release of the documentary film Atarashii kamisama 新しい神様 (English title: The New God) by Tsuchiya Yutaka 土屋豊 in 1999, the band and especially the female singer Amamiya Karin 雨宮処燷 attracted the attention of the Japanese media (Takaizumi 2005: 53). By the turn of the millennium, Amamiya turned her back on the right-wing scene. Since around 2005, she has been appearing in public to address problems of the socially deprived. As a consequence of Amamiya's retirement, the trio disbanded, but the guitarist Itō Hideto 伊藤秀人 continues Ishinsekiseijuku as a singer-songwriter project (Ishinsekiseijuku: Itō Hideto 2013). 
Patriots are like the blossoms of the mountain cherry/ Unnoticed by the people they blossom, fall and die/ The only thing that never ceases is veracity/ The pride sprung from our fatherland/ Strike down the soulless with the sledgehammer/ The only thing we aim forthe beheading of you bastards [...] (Tettsui 鐵桘 2004: “Aikokusha-fu” 愛國者賦 [Patriot Song]).

\section{Pride in the bloodstream: Chi and hokori}

One essential feature of the imagery that the collective identity of the type of rock music under consideration is based on is the idea of a blood bond, which is reflected in the frequent usage of the terms 'chi' 血 (blood) and 'chishio' 血潮/血汐 (bloodstream). Blood comes up primarily in the context of two topical fields. First, blood is portrayed as the bodily element that is responsible for human aggression. Second, by singing about blood the lineage of the in-group is glorified and sometimes a racially defined line of descent is constructed. By emphasising the notion of ancestry and the inheritance of blood, certain obligations to the Japanese nation are suggested to the listener. Furthermore, the aggression that is thought to emanate from the blood is in many cases interpreted as a result of inheritance:

In the blood of our race flows a burning will to fight/ You young people who lost your vigour!/ Remember our symbol/ Passionate, burning red on truthful white [...] (Strong Style 2001: “Kokki ni keirei o" 国旗に敬礼を[Salute to Our National Flag]).

The disposition to bellicosity expressed in these quotations resembles the concept of 'yamatodamashii' examined above. The will to fight is portrayed as innate to the 'Japanese spirit' within all Japanese people and is also passed on genetically through blood. On the basis of the rationale that due to their blood bond the Japanese people are destined to fight, a lineage of warriors is constructed that ranges from ancient times to the present. In this connection it is suggested to the listeners that, in addition to a common spirit, they are bonded by blood to various martial archetypes from the past, which involves warriors from pre-modern periods, as well as soldiers from the 20th century, such as the pilots of the tokkōtai 特攻隊 (special attack units) that are better known as 'kamikaze pilots' outside of Japan:

The blood of the Yamato warriors runs also through your veins [...] (Strong Style 2001:

"Sokoku no tame ni").

The peace that we have today in our fatherland we owe to you/ We are proud that the same blood is running through our veins/ Having held his newborn child not even once the young soldier flew away/ To save the children of tomorrow, he sacrificed his own body [...] (Shiden 紫電 2004a: “Aoki sora” 蒼き空 [Blue Sky]).

The latter quotation involves an idea of 'pride' (hokori 誇り) that is based on an alleged blood bond with the soldiers of the Pacific War. Furthermore, being proud of 
one's blood is sometimes declared as the common ground of the in-group, as the following quotation illustrates:

There's pride in the red blood that's running through your veins/ In this unruly world we hold on to our will of iron under the waving flag of loyalty/ As long as we have honour, glory, and will/ We inflame our spirit and sacrifice our blood/ Oh my comrades in proud solitude! Let us rise [...] (Resolute Immortal Partizan 2000: “Kokorozashi” 志 [Will]).

Such racially defined representations of collectivity can be seen as an attempt to integrate the listener into the in-group by stressing the notion of lineage. The manner in which the term 'blood' is related to concepts such as 'pride' (hokori), 'honour' (meiyo 名誉), or 'glory' (eiko 栄光) is a reminder of the symbolism of the international right-wing extremist organisation Blood \& Honour. Founded in 1987 by the aforementioned vocalist of the English band Skrewdriver, Donaldson, the organisation continues to have a strong influence on right-wing rock, especially in Europe, but also in other regions (Raabe 2008: 88). Donaldson is reported to have had some influence on the formation of the Japanese right-wing rock scene. ${ }^{16}$ A relatively obvious reference to Blood \& Honour appears on the album of the band Bull the Buffalos that features a song called “Chi to meiyo” 血と名誉 (Blood and Honour):

Blood and honour!/ We won't let them snatch away our beloved fatherland/ Bring back the purity along with the unrelenting spirit/ Take the courage to fight against the looming foreign powers/ Don't forget the pride of being Japanese and protect yourselves/ Your swelling hot bloodstream is the proof of the Japanese spirit/ Blood and honour! [...] (Bull the Buffalos 1993: "Chi to meiyo").

Noteworthy in this respect is that although mentioned as often as 81 times in the examined lyrics, both the verb 'hokoru' 誇る (to be proud) and the corresponding noun 'hokori' (pride) are otherwise rarely used in Japanese. While in other languages such as English or German the phrase 'to be proud' may be used without giving it much thought, in Japanese 'hokoru' carries a rather negative connotation and is normally used with the meaning of 'boasting' or 'acting superciliously'. The consistently positive usage of pride in the type of rock music under consideration indicates that, along with musical style and fashion, some Western concepts were adopted. This might be due to the fact that most of the bands take British skinhead music as a stylistic guideline. As Florian Sieber points out, within the several currents of the skinhead subculture the term 'pride' holds a central position. Initially predominantly used in terms of 'working-class pride', in the course of the secession of nationalist and right-wing extremist groups, 'pride' was re-interpreted in the sense of 'national pride' (Sieber 2008: 155). Working-class pride or a cult of proletarian

16 In an interview, Nakatani Ryūichi 中谷隆一, one of the first Japanese musicians to play right-wing rock, states that in the late 1980s members of the Japanese right-wing rock scene were in contact with Donaldson (Zero Magajin 2011). 
imagery, which are vital elements of the many shades of Western skinhead music, are absent in the examined type of rock music. Here pride comes up exclusively in the contexts of national or racial belonging:

You deride the truth-are you my enemy?/ The reckless words of instigators pervert people's thoughts/ This soil is controlled and covered by phantasm/ This country is your pride!/ Realise that and stand up! [...] (Kaiga 嵬峨 2010: “Kyokō” 虚構 [Phantasm]).

What I should believe in - my strength/ What should be protected - the dream/ What I should be proud of - my blood/ What I should abide by—the commandment [...] (Tettsui 2004: “Nippon ōkami”" 日本狼 [Japanese Wolf]).

While the term 'blood' is used with a positive connotation throughout the lyrics, it should be mentioned that in Japan blood is usually connected to ideas of impurity and maculation. This principle, referred to as 'kegare' 穢れ, to some extent defines blood as taboo (Vollmer 2006).

Stand up to protect: Me o sameru, tachiagaru, tachimukau, mamoru, and torimodosu

The lyrics of the type of rock music under consideration are in part characterised by agitation. What is of importance in this respect is the word 'ima' 今 (now), through which a particular urgency is conveyed. In the examined lyrics the present times are frequently depicted as a misguided age in which the state of affairs is gradually going from bad to worse, with Japan and the Japanese people teetering on the brink of the abyss and where immediate action is necessary:

'Wake up, Japanese people!/ Our fatherland is going under/ Let's protect this country with our hands [...]' (Strong Style 2001: "Dakkan Nippon” 奪還日本 [The Re-conquest of Japan]).

In addition, the present times are described as highly complicated, making it almost impossible to decide what is worth believing:

In this situation where you can't decide between truth and lie/ Now!/ In this country full of errors/ The answers that nobody will give you, whoever you ask/ Find them! Find them!/ Without relying on anybody [...] (Miburō 壬生狼 2001: “Kotae o mitsukedase” 答えを見 付け出せ [Find the Answers]).

In many lyrics this complexity of today's reality appears to stem from a planned deception of the public by politics and the media, which is expressed through the term 'itsuwari' 偽り (deceit/scam). This term is ascribed to a vaguely defined ruling class referred to as 'shihaisha' 支配者 (those in control): 
You people who are manipulated by those in control/ Come to your senses!/ Bite those mad dogs to death! [...] (Raiya 2005: “Shiroki akuma” 白き悪魔 [White Devil]).

Hey you young people who have no doubt in our forced constitution and the politics of deceit!/ The mass media is a machinery that helps those dumbasses who try to weaken this country [...] (Nakatani Ryūichi 中谷隆一 1990c: “Heisei-ishinrō” 平成維新狼 [Wolf of the Heisei Restoration]).

The argument that the Japanese public is being tricked by diverse powers within and outside of Japan serves as a basis for agitation and is often accompanied by a call to wake up from illusion or lethargy. This call becomes manifest in the use of the signal word ‘(me o) sameru’ 目を覚める/醒める (to wake up/to come to one’s senses). Such awakening implies the recognition of the deceit, as it is described in the lyrics. However, mere recognition of the deceit is not regarded as enough, so in a second step of agitation the audience is incited to rebellion, which is often reflected in the two signal words 'tachiagaru' 立ち上がる (to rise/to stand up) and 'tachimu$k a u$ 立ち向から (to resist/to fight against):

Where is my Japan going?/ My Japan is going to rack and ruin/ Fatherland Japan is crying/ Wake our fatherland Japan/ Stand up people!/ Stand up Japanists! $/{ }^{17}$ Wake up Japan!/ Wake up Japanists! [...] (The Hawks 2007: “Nipponshugisha” 日本主義者 [Japanists]).

Wake up immediately!/ Fight for Japan!/ Recall your soul from the bottom of hell/ Inflame your heart/ Search what is lost with these eyes/ Protect everything you find with these hands [...] (Strong Style 2001: "Sokoku no tame ni").

The latter of the above quotations contains a term that leads to another form of agitation: following the appeals to awaken and stand up, the audience is told to protect or defend certain material and immaterial values. The two signal words 'mamoru' 守る/護る (to protect) and 'mamorinuku' 守り抜く護り抜く(to protect to the end) suggest that the protection of Japan and her people and culture lies in the hands of the in-group. This kind of defensive attitude that aims to protect what is considered to be unadulterated Japanese culture against foreign influence is emphasised throughout large parts of the examined lyrics and is for instance expressed as follows:

We have no shield to protect what deserves protection/ The only thing we believe in is money and we drown in a sea of greed/ Do your heroes have blue eyes?/ Is it such pain to be proud of your country? [...] What's admired is the foreign countries, what's thrown

17 Japanism (Nipponshugi) was a nationalistic current opposed to Western liberalism that emerged among Japanese intellectuals by the time of the First Sino-Japanese War (Doak 2007: 223; Linhart 1994: 145-146). It is not clear whether this song is intended to refer to this particular historical body of thought or if the band simply likes the idea that 'Japan' (Nippon) can be made into an '-ism' (-shugi). 
away is the fatherland [...] (Nakatani Ryūichi 1990b: “Waga eiyū, sono tamashii” 我が英 雄, その魂 [Our Hero, That Spirit]).

Another concept that is of importance in this context is the restoration of certain values or ideas, which is articulated through the signal word 'torimodosu' 取り戻す (to restore/to regain). While the term 'mamoru' (to protect), which is exemplified by the above quotation, comes up where it is considered necessary to protect or conserve certain values that are imagined to be in danger of going astray, 'torimodosu' reflects a call to bring back values that are thought to be lost already. Such lost values mentioned are for instance the pride of belonging to the Japanese people, a distinctive 'national character', and the sovereignty of the in-group (warera) over Japan:

Regain the pride of the Yamato race/ Protect the Japanese heart to the end/ Believe in your strength and smash the enemy [...] (Hien 飛燕 2005: “Yamato” 大和 [Yamato]).

Restore the Japanese tradition/ Wake the Japanese pride/ Sustain the Japanese culture/ You little wannabe-Americans of unknown nationality [...] (J.U.U.M. 2004: "Don't Wanna Be the Petite-American").

The desire to restore an ideal state of affairs that is believed to have existed in an unascertained past becomes manifest in many of the examined lyrics. The globalisation of culture, as reflected especially in the last of the above quotations, is apprehended as a threat to one's own identity. Particularly the adoption of American culture (by Japanese youth) is viewed as a betrayal not only of Japanese tradition and culture, but ultimately also of the (Japanese) self.

\section{The evanescence of life: Sakura}

As an example of the utilisation of national symbols the Japanese flowering cherry sakura 桜/櫻 shall be discussed below. In the examined lyrics the symbol of the cherry blossom comes up mainly in the context of the topos of the transience of human existence and as an allusion to kamikaze. What has to be noted in advance is that the following considerations of the cherry blossom should be taken primarily against the background of its nationalistic representations in the type of rock music under consideration, but the symbol of the cherry blossom in itself is not necessarily of a nationalistic connotation.

Like the term 'yamatodamashii', the symbolism of the cherry blossom has undergone constant change throughout the course of history. According to a study on the Japanese aesthetics of the cherry blossom by Emiko Ohnuki-Tierney, the significance of cherry blossoms initially had a strong connection to the worship of rice, since agrarian beliefs of fertility involved the idea that-in spring, when the cherry 
trees lose their blossoms - the mountain deity descends to the rice paddies on the falling petals of the cherry blossoms to look after agricultural production (2002: 29). In classical Japanese literature such as the Man'yosh $\bar{u}$ 万葉集 (7th-8th century) the symbol of the cherry blossom was still scarcely represented and overshadowed by the motif of the plum blossom, which was adopted from Chinese aesthetics (ibid.: 53). Owing to a shift of the Japanese relationship with China, by the end of the 9th century the development of a particular style came to the fore within Japanese arts (ibid.: 54). By the early 10th century, the cherry blossom in full bloom-as a metaphor for women, splendour, and vitality - became an important motif of Japanese poetry. However, as the literary focus moved from the blooming to the falling of the cherry blossom, the symbol was increasingly associated with the impermanence of life and love - and ultimately also with death (ibid.: 39-40).

This topos of the impermanence of life is also represented in parts of the examined lyrics. Drawing on the motif of falling cherry petals some bands refer to the aesthetical principal of 'mono no aware' 物の哀れ, which can be explained as a quality that evokes a gentle feeling of wistfulness in the appreciation of things that will soon vanish (Parkes 2011). Particularly some of the lyrics of the band Tettsui stand out in their lyrical style that is characterised by emotional pathos in combination with archaic wording:

Search for the Promised Land ${ }^{18}$ of life [and you will get to] know the shame of life/ The ephemerality of life randomly makes the cherry blossom of the spring night vanish/ Our soul is struggling in desperate agony [...] (Tettsui 2004: “Homura” 焰 [Flame of Passion]).

The symbolism of falling cherry petals played a significant role in the ideological fundament of Japanese militarism from the Meiji Era (1868-1912) onwards. The philosopher Nishi Amane 西周, who played an important role in Japanese modernisation, but who was also a central figure in the development of the modern Japanese military, used the cherry blossom as a metaphor for the positive qualities of the Japanese people. In a series of lectures that laid the foundation for the Imperial Rescript to Soldiers and Sailors of 1882, Nishi proclaimed the superiority of the cherry blossom, arguing that unlike other flowers such as the peony (the emblem of China) or the rose of sharon (the emblem of Korea) it does not stay on the branches until rotten. Nishi's idea that the 'virtue' of the cherry blossom has to be seen in 'not clinging to their blooming' was of relevance as an ideological basis for Japanese militarism since 'dying without clinging to life' (isagiyoku shinu 潔く死ぬ; literally 'dying unsoiled and with integrity') was later propagated by the Japanese state to motivate soldiers to hurl themselves into the fray (Ohnuki-Tierney 2002: 106-107).

18 'Promised Land' is used here to translate the archaic Japanese word mahoroba まほろば that, according to Michael F. Marra, is used in the Kojiki as the name of a land of absolute bliss, which refers to Yamato (2007: 12). 
In the examined lyrics the self-sacrifice for the good of the nation is a frequently used topos; dying for the empire however, is explicated in only one song:

'We show you our way of dying!/ We fall with the blossoms, for the Japanese empire [...]' (Ishinsekiseijuku 1999: "Niitakayama nobore"19 ニイタカヤマノボレ [Climb Mount Niitaka]).

While Nishi had a major influence on the promotion of soldierly self-sacrifice for the emperor, he did not develop the metaphor of falling cherry petals and falling soldiers (Ohnuki-Tierney 2002: 107). According to Ohnuki-Tierney, this specific metaphor originated from the Yasukuni Shrine, which advanced to a centre of attraction for Japanese militarist ideologists. From 1933 to 1935 the Shrine issued a military history in five volumes dedicated to the fallen soldiers loyal to the emperor. Symbolising the soldiers who sacrificed their lives for the emperor, each volume was decorated with the image of falling cherry petals (ibid.: 107-108). Keen to propagate the militaristic connotation of the cherry blossom, the military disseminated the idea that soldiers who are scattered in battle like cherry petals will be reborn as cherry blossoms in the Yasukuni Shrine (ibid.: 109). Although the Yasukuni Shrine is not mentioned in this connection, the idea of reincarnation as a cherry blossom can also be found in one of the examined lyrics:

The blossom is the proof that I'm alive/ The pure, sincere cherry blossom blooms in my heart/ Even if I went under, I'd vividly dance up into the skies [...] (Yoroi 鎧 2003: "Geki" 檄 [Manifesto]).

The allusion to the idea of reincarnation as a cherry blossom gets lost in the above quotation, since the translation of the last verb 'dance up' does not fully encompass the meaning of the Japanese original. Therein the unusual word 'sosorimaichiru' そ そり舞い散る is used—a compound of the three verbs 'sosoru' 唆る (to tower/to arise), 'mau' 舞う (to dance), and 'chiru' (to fall/to die off). In all likelihood, in the context of the above lyrics the verb 'chiru' refers to a falling cherry petal. In addition the precedent verb 'mau' signifies the circling downward motion of a falling cherry petal. Paradoxically, however, this downward motion is at the same time directed up into the sky, which can be interpreted in terms of the resurrection of the spirit.

The equation of falling cherry petals and falling soldiers saw its climax during the final stage of the Pacific War when the image of the tokkotai (special attack units) was glorified by state propaganda. The squadrons sent to Pearl Harbor were also called 'tokkōtai', but they were meant to return after the attack. The kamikaze

19 'Niitakayama nobore' was the code radioed by the Japanese Air Force to confirm the attack on Pearl Harbor; 'Niitakayama' was the Japanese name for Mount Yu-shan in Taiwan (Frédéric 2002: 711; Johnson 2006: 49). 
strategy as such, implying a fatal crash into the enemy, did not come into operation before 1944 (Ohnuki-Tierney 2002: 159). Admiral Ōnishi Takijirō 大西瀧治郎, the initiator of these suicide missions, utilised the militaristic connotation of the cherry blossom naming all of the nine squadrons that came into operation in the first tokkōtai attack at the Battle of Leyte Gulf with reference to the cherry blossom (ibid.: 163-164). Of the examined lyrics at least two suggest a reference to one of these squadrons, the Wakazakura-tai 若桜隊 (Corps of the Young Cherry Blossoms):

Beyond the white clouds, across the wide, blue sky fly the red dragonflies with shining eyes/ For the ones they love they wipe away their tears/ The young cherry blossoms who fall with the echo of their engines [...] (Akiakane 秋茜 2004: “1945”).

Oh you brave shishi! ${ }^{20}$ Wild eagles who fell from the sky/ Oh you proud young cherry blossoms! Heroic spirits that bloom on the chigiriki [契り木] [...] (Yoroi 2003: “Tenka no seiei/Chirite mo ato ni kaoru hana” 天下の精鋭 散りても後に薰る華 [The Elite of the World/A Flower that Smells Sweet Even After It Fell]).

These two quotations contain several references to kamikaze that are worth further explanation. The image of red fireflies (akatonbo 赤とんぼ) that comes up in the first quotation refers to the popular folk song "Akatonbo". ${ }^{21}$ However, as Akiakane point out on their website, 'akatonbo' was also a vernacular name for a type of aircraft that was originally used for training but as a last resort came into operation in tokkōtai attacks (2006). The second quotation in contrast equates the tokkōtai pilots with the shishi, whereby the idea of a lineage of warriors is supported. Also of relevance in this respect is the expression 'wild eagles' (arawashi 荒熟), which was used in Japanese wartime propaganda as a name for daredevil pilots. Possibly the band adopted this image from the military song "Arawashi no uta",22 荒熟の歌 (Song of the Wild Eagles). Moreover in this quotation the term chigiriki is used in a polysemous manner. In fact, a chigiriki is a flail weapon. However, the depiction of something blooming from it indicates that the term includes another meaning. Presumably the band played on the original meaning of the Chinese characters used in the term 'chigiriki', a compound of 'chigiru' 契る (to vow) and 'ki' 木 (wood/tree). Given the context that the term is used in, it can be assumed that by 'chigiriki' the band did not only mean the weapon, but also a literal 'tree of the vow'-which can be understood as an allusion to the cherry tree. Without a doubt, the image of 'heroic spirits' (eirei 英霊; actually used as 'spirits of war heroes')

20 The term 'shishi' 志士 (sometimes translated as 'men of high purpose') refers to radical activists of the Bakumatsu Period (1853-68) who tried to repel growing foreign influence through terrorist attacks (Jansen 2002: 326-330). As Shillony points out, the ultranationalist officers of the Japanese military, who attempted a coup d'état in 1936, saw themselves as the shishi of their times (1973: 58).

21 Written in 1921 by Miki Rofū 三木露風 and composed by Yamada Kōsaku 山田耕作 in 1927.

22 Written and composed in 1938 by Azuma Tatsuzō 東辰三 (Kindaichi and Anzai 1990: 220-221). 
blooming on this tree refers to the idea of the reincarnation of soldiers as cherry blossoms mentioned above.

The reference to the symbolism of the cherry blossom is also of importance because it contains the topical element of youthfulness. The equation of the short-lived cherry blossom and the tokkotai pilots, who usually died at a very young age, serves as a basis for the embellishment of death. The representation of a heroic selfsacrifice provides a possibility for both the musicians and the audience to indulge in an imagination of daredevilry, heroism, and national pride. What is noteworthy in this regard is that the, in most cases, disastrous outcome of this kind of 'heroism' is by no means excluded in the examined lyrics. Rather the fatality of the tokkotai pilots is described in detail, as the following lyrics exemplify:

\begin{abstract}
My bones become a cluster bomb/ Even if my life comes to an end, the pride that's blooming in my heart will blossom and scent in all eternity/ Kamikaze!/ At the farthest ends beyond the drifting clouds pure as pure can be the snow is gently falling/ My body becomes a six-foot sword as I hear the requiem of those who'll die/ The wild blooming of the cherry blossom/ A cup of water before I bid farewell/ ${ }^{23}$ And life is scattered to the wind/ My bloodstream falls and goes up in flames as my heart longs for the fields and mountains of home/ Glorious are the souls of the heroes [...] (Tettsui 2000: “Hakanaki hana yo" 儚き花 よ [Oh Fleeting Blossom]).
\end{abstract}

Even though the actual word 'kamikaze' is mentioned only three times throughout the examined lyrics, kamikaze as a topical element is vital to the type of rock music in question. As the above examinations illustrate, the imagery of falling cherry petals is utilised to allude to the topic in various ways. The tokkōtai attacks are thus romanticised as an act of utmost bravery, whereby in many cases the tokkotai pilots are idolised and used as objects of identification.

\title{
The topical properties of the lyrics
}

Following the preceding analysis of the linguistic properties of the lyrics, the examinations of the upcoming part shall focus on some of the fundamental topical elements of the subject of enquiry. Two representative topical areas shall be analysed and discussed against the background of quotations from the examined lyrics.

\section{Handling Japan's wartime past: Reinterpretation, justification, and revisionism}

As parts of the above examinations have shown, the vocabulary of the type of rock music in question is to some extent characterised by a rhetoric that is borrowed from

23 This verse refers to 'mizusakazuki' 水盃 (literally 'a sake cup of water'), the ritual of drinking water from a sake cup in the event of a farewell where a reunion is uncertain (Nihon daijiten kankō-kai 1974: 554). 
ideologies that originated before the end of World War II. With a few exceptions the examined bands predominantly concern themselves with topics related to the past. The historical background that the majority of the lyrics refer to spans roughly speaking from the Bakumatsu Period (1853-68) to the end of World War II, whereby the focus of attention lies on the time between the Manchurian Incident (1931) and the end of the Pacific War-a period that is often referred to as Jügonen-sensō 十五年戦争 (The 15-year War) in academic or left-leaning historiography. That is to say that the examined type of music sports an approach towards history that attaches the biggest importance to wars. As a result many of the examined lyrics debate problems that emerged from war or deal with the question of the accountability of the Japanese wartime generation.

Generally speaking three modes of handling Japan's wartime past can be located in the type of rock music under examination. The first is the reinterpretation of both Japan's motivations to go to war and her role as an aggressor. Particularly with regard to the Pacific War, the Japanese actions are often portrayed as defensive warfare. The second mode is the justification of aggression through the reproduction of the idea that Japan was impelled by noble aims. In this manner, mainly the invasion of Asian neighbouring countries is construed as an attempt to free Asia from the subjugation by Western powers. The third mode of handling Japan's wartime past is revisionism, which may imply the discrediting of prevalent historiography or the actual denial of historic events.

In the type of rock music under consideration the reinterpretation of Japan's wartime past is largely based on the notion of victimhood. Rather than the questioning of accountability, many of the lyrics emphasize the hardships of the Japanese soldiers and civil population, which are associated with heroic devotion to one's country and honourable self-abandonment. Arguing that this generation should not have suffered or died in vain, it is suggested to the audience that the ideological legacy of those times has to be sustained. Abandoning or criticising the mentality of this generation is portrayed as a betrayal of the ancestors:

We won't let the tears you shed back then be betrayed/ The Volksgeist of those who were born after everything was over is weakening/ [We however] shall fulfil the mission that was assigned to us by you/ [We pledge] an oath on blood and tears [...] (Strong Style 2001: “Chi to namida e no chikai” 血と涙への誓 [The Oath on Blood and Tears]).

Another approach to Japan's wartime past can be found in the emphasis on the idea that her opponents forced Japan into defensive warfare. In this context it is argued that the Japanese military acted merely in purpose of national defence, whereas the tokkōtai attacks were carried out against the background of Japan's natural interest to secure her future. Referring to historical events, the band Ishinsekiseijuku provides an in-depth insight into this kind of view on Japanese warfare, arguing that 
trapped by the Anglo-Saxon dominated world economy Japan had no other choice but to attack Pearl Harbor:

Niitakayama nobore!/ In the face of the War Plan Orange, ${ }^{24}$ the Hull note, ${ }^{25}$ the embargo, ${ }^{26}$ and the encirclement of Japan by America, Britain, China, and the Dutch 'Pearl Harbor' was a necessary evil/ Tora! Tora! Tora! [...] (Ishinsekiseijuku 1999: "Niitakayama nobore").

While in this manner Japanese warfare is portrayed as enforced by historical circumstances, some of the examined lyrics contain accusations towards the opponents. In the context of the Pacific War it is first and foremost the US who are held responsible for the war. They are accused of an unfair, invasive warfare, driven by greed. In the example below, topics that are unrelated to the war are mentioned in order to discredit the opponent:

Since MacArthur, through guile and aggression, America makes us dance the merry dance of democracy/ The freedom-loving, open-hearted Uncle Sam/ (Be conscious of that! Be quick! Please my BABY! Before your heart is violated by his greed.) ${ }^{27}$ Asia, Africa, and the black slaves - do you also want [to own] the stars, America?/ Seeking the bizarre and taking possession of it with a gun/ The Anglo-Saxon history is a history of massacres [...] (Akiakane 2004: “Uncle Sam”).

A crucial aspect of this quotation is the term 'aggression' (shinryaku 侵略), which is ascribed to the US and is a determinant of the representation of the Japan-US relationship in this music. The US' interference with the Japanese expansion into the Pacific area is generally described as an invasion and the US is defined as the aggressor. Japan's invasion of the neighbouring Asian countries in contrast is not regarded as such. Drawing on militaristic doctrines of justification some of the examined bands explicate Japanese imperialism and expansionism on the basis of honourable causes.

One concept that can be understood in these terms is the idea of a war of liberation, which is reflected in the term 'Greater East Asian War' (Daitōa-sensō 大東亜 戦争). Although explicitly mentioned in only one song, the term 'Greater East Asian War' is symptomatic of the prevalent comprehension of Japanese warfare in Asia:

24 Launched in 1907, the War Plan Orange was a strategy to prepare the US Navy for the possibility of a war with Japan, envisaging the capability of moving the entire fleet from the Atlantic to the Pacific coast (Jansen 2002: 449).

25 Named after the then State Secretary Cordell Hull, the Hull Note was a draft for a treaty between the US and Japan that as one condition for the cancellation of the embargo on oil exports to Japan demanded the complete withdrawal of Japanese troops from China and the Indochinese Peninsula (Krebs 2010: 247-248).

26 As a reaction to Japan's invasion of Southeast Asia the US, the UK, and the Dutch East-Indies imposed an embargo on Japan in August 1941 (ibid.: 77-90).

27 This verse is in English in the original. 


\begin{abstract}
Now, half a century after the end of the Greater East Asian War, the minds of Japanese citizens are still under the occupation of the United States/ The natural order that we maintain is not based on laws or obligations, but traditions that accumulated in the course of the 2000 years of our history [...] On a world map from a century ago Asia is covered with the colours of the imperialist flags of Western countries/ Only white Anglo-Saxons were considered as humans, while Japan advocated racial equality/ But that created even more racial discrimination/ Invasion/ Rape/ Racism/ Manifest Destiny/ In the spirit of hakkō $i_{c h i u}{ }^{28}$ the Greater East Asia Co-prosperity Sphere was planned/ Of the coloured races only one nation stood up against the major powers to break their haughtiness/ Japan's just war initiated the independence of Asia/ After chasing out the West, the world map changed completely/ That heralded the end of the age of imperialism [...] (J.U.U.M. 2004: "Kuni, yasukare”国, 靖かれ [Fatherland, Rest in Peace]).
\end{abstract}

The term 'Greater East Asian War' implies a war waged to unite East Asia into a single empire, which was envisioned as the 'Greater East Asian Co-prosperity Sphere ${ }^{29}$ (Daitōa-kyōeiken 大東覀共栄圏), mentioned in the lyrics above. In a lecture on the intellectual history of Japanese Pan-Asianism, Matsumoto Ken'ichi 松 本健一 argues that the idea of the Greater East Asian War was of vital importance to the justification of the invasion of Asia. According to Matsumoto, the idea of a unified Asia was considerably influenced by the book Tóyō no risō 東洋の理想 (The Ideals of the East, 1903) by Okakura Tenshin 岡倉天心, which contains the phrase 'Asia is one'. This sentence was later utilised as a basis for the idea that the Japanese Imperial Army should consolidate Asia, which will then, spearheaded by Japan, confront the West (Matsumoto 2007: 17). In this context Matsumoto quotes Takeuchi Yoshimi 竹内好, who after the war criticised the notion of the 'liberation of Asia' as an excuse. In Takeuchi's opinion the war Japan waged in Asia should

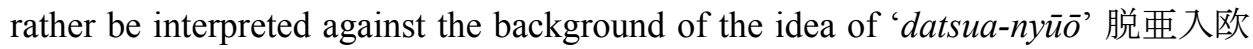
(departing from Asia, approximating Europe). By subjugating the Asian neighbouring countries, Japan tried to accelerate modernisation and eventually became similar to Europe (ibid.).

Since the end of World War II the use of the term 'Daitōa-sensō' is largely avoided for its militaristic associations. The occupation forces recommended to use the term 'Taiheiyō-sensō' 太平洋戦争 (Pacific War) instead (ibid.: 11). However,

28 The compound hakkō ichiu 八紘一宇 (literally “eight cords under one roof”) is derived from the Nihongi, where it comes up in the mythological accounts of Jinmu-Tennō's successful conquest of the aboriginal people of the Japanese islands. By bringing all eight corners ('eight cords') of the archipelago under his rule ('one roof') he fulfilled his heavenly task. In the early 1900s Tanaka Chigaku 田中智学, a scholar of Nichiren Buddhism, deduces from these lines that heaven has appointed one person, Jinmu-Tennō, to unify the world. Tanaka interpreted 'hakkō ichiu' in the sense that it was not just the eight corners of Japan, but moreover the eight corners of the world that should be under the Emperor's rule (Lee 1975: 28-29). This kind of exegesis of the Nihongi fuelled ideas of expansionism and later hakkō ichiu became a fundamental part of militaristic thought.

29 For a discussion on the ideological foundations of the Great East Asian Co-prosperity Sphere see Duus 2008. 
since this term focuses on the war between Japan and the US, the term 'AjiaTaiheiyō-sensō’ アジア太平洋戦争 (Asia-Pacific War) became standard in recent times in an attempt to emphasise that Japan waged war both in Asia and in the Pacific (Yamazaki 2006: 157-158).

Besides the modes of handling Japan's wartime past that were discussed so far, some lyrics show a tendency towards negationism, i.e. the denial of the findings of prevalent historiography. In such lyrics, the question of accountability is countered not (only) by stressing the idea of the noble aim of liberating Asia, but the historiographical position that Japan acted as an aggressor is declared untrue. In the case of a few explicit lyrics the accounts of wartime atrocities committed by the Japanese Imperial Army are dismissed as fiction, which is most unambiguously expressed in a song by Nakatani Ryūichi:

The Tōkyō Trials were a complete farce/ Without ever telling us the truth, it has been forced down our throats that Japan has incited the war and carried out massacres in Shi$n a /^{30}$ Throw them away, throw them away/ The textbooks that say such things/ Nothing but lies, nothing but lies/ The Reds are trying to bullshit you [...] (1990a: "Tamashii o nukareru mae ni” 魂を抜カレル前ニ [Before You Are Deprived of Your Soul]).

The term 'massacre' (tairyō gyakusatsu 大量虐殺) used in the above quotation probably refers to the Nanking Massacre, which is one of the most intensely debated issues relating to Japan's wartime past. Parts of the Japanese far-right faction advance the position that the massacre never occurred and that it is a mere construct of a historiography that was established by the occupation forces. What is also of importance in this regard is the problem of coming to terms with wartime history in school education, which is referred to in the lyrics above by the issue of (history) textbooks. The quoted song was released in 1990 and therefore a few years prior to the foundation of the controversial Atarashii rekishi kyōkasho o tsukuru-kai 新しい 歴史教科書をつくる会 (Japanese Society for History Textbook Reform), but, as Sven Saaler points out, the society's foundation had been preceded by a long history of revisionist tendencies in politics (2005: 71-80). Significant in this respect is the song's reference to the Tōkyō Trials, since views on history that accept Japanese war crimes as proven are dismissed by parts of the Japanese conservative and farright faction by the term ‘Tōkyō Trial view of history' (Tōkyō saiban shikan 東京裁 判史観). This denomination implies the position that Japan was a wrongly convicted victim of those who emerged victorious from World War II, and that the Tōkyō Trials have introduced a biased historiography to the disadvantage of Japan (Takatori 2008: 81-82). In some of the examined lyrics, those who do not disbelieve the

30 Originally a neutral toponym for China, today the term 'Shina' 支那 has a derogatory connotation (Fogel 1995: 69-75). 
prevalent view of history are defamed and the audience is incited to take action against them:

\begin{abstract}
Without questioning the fictional history those cowards are laughing at their own country/ The red blood that's running through your veins you inherited from the past, so show your pride/ Fake patriots feign love for their country and lament about the fatherland/ It is our duty to purge [Japan from] the traitors to the nation that talk about patriotism for their own profit [...] (Tettsui 1992: “Jinrō butai/Werwolf” 人狼部隊/Werwolf ${ }^{31}$ [Werewolf Troop/Werwolf]).
\end{abstract}

The expression 'fictional history' (kyokō no rekishi 虚構の歴史) used in these lyrics without a doubt refers to the historiographical debate on Japanese war crimes, whereas this rhetoric bears a striking resemblance to the contested book "Nankin gyakusatsu” no kyokō “南京虐殺”の虚構 (The Fiction of the “Nanking Massacre") $)^{32}$ by the historian Tanaka Masaaki 田中正明 (1984). Although the book was published only a few years prior to the 1992 release of the song quoted above, it would be untenable and somewhat exaggerated to claim that Tanaka's book had influenced the band Tettsui in their word choice. However, this rhetorical analogy illustrates the ideological proximity to Japanese historical revisionism or negationism that is intrinsic to large parts of the type of rock music under consideration.

In summary it can be determined that some of the attitudes expressed in the examined type of rock music concur with right-wing extremist positions. The viewpoint that the efforts of the Japanese wartime generation must not be disregarded can also be found in the declaration of intent of the Atarashii rekishi kyōkasho o tsukuru-kai (Tsukuru-kai 1997). The idea that the invasion of Asia was in fact a war of liberation, the 'Greater East Asian War', which in the long run would have resulted in a unified, pacified East Asia, is often utilised for the justification of Japan's warfare. One prominent example of the post-war period is the controversial book Daitōa-sensō kōtei-ron 大東西戦争肯定論 (Approval of the Greater East Asian War) by Hayashi Fusao 林房雄, which was published in 1963 and obtained approval among parts of Japanese politics as well as the general public (Duus 2008: 152; Saaler 2002: 26). In recent years for instance the popular manga of Kobayashi Yoshinori 小林よしのり contributed to the dissemination of the view of history that Japan was not an aggressor but a liberator.

31 This song is taken from a record released by the American label Vulture Rock Records. Presumably because it was also intended to be sold on the non-Japanese market, the songs have Japanese as well as English titles.

32 Also published in English in the year 2000 under the title What Really Happened in Nanking: The Refutation of a Common Myth (Tanaka 2000). 


\section{Violence and masculinity}

Another significant characteristic of the phenomenon in question is the definite male predominance. With the exception of the female trio Akiakane and Amamiya Karin 雨宮処凛, the examined bands are all-male. This male predominance of the band line-ups is also reflected in a preoccupation with topics related to maleness. In this respect the type of rock music under consideration can be understood as an example of a homo-sociological form of popular culture. While representations of martial masculinity are a decisive topical element of the examined lyrics, topics related to women are only mentioned in two of the 180 lyrics analysed. In these two lyrics the portrayal of harmless, loving womanhood serves as a contrast to callous maleness. Women are depicted either as tender creatures or associated with the image of a caring, motherly wife:

Men! Fill your trembling bodies with vigour and struggle through!/ Women! Be fragrant and tender like the wide soil [...] (Sardonic Smile 2005: “Asane” 朝寝 [Sleeping In]).

The storm at night shakes the town from left to right/ The raindrops are pattering against the windowpane while the woman is worried about her spouse and dreams about the open sea/ 'I won't break my promise' swears the man with a smiling face while the fishing lights are dazzling [...] (Empi 猿臂 2007: “Isaribi”漁火 [Fishing Lights]).

The latter quotation suggests an idealisation of conventional gender relations. While the man sets out to the rough, dangerous world of the open sea, the woman stays at home. In both quotations the image of women serves first and foremost as an enhancement of the concept of men. The antithesis of sensitive, timid womanhood tied to agriculture or housekeeping consolidates the image of the fearless, tough male warrior, labourer, and conqueror.

According to Kurt Möller, in Germany it is primarily young men who form the basis of far-right groups, a fact that can to some extent be explained by the predominance of violent behaviour within right-wing extremist environments. Möller posits that it is precisely this prevailing atmosphere of violence what intrigues young men. The attractiveness of right-wing extremist environments lies not so much in the political ideas they offer as in the possibility for young men to perform a violent self-concept. The resulting violent demeanour is only later explained in accordance with ideological principles (Möller 2010: 28-29). Although the situation of rightwing extremism in Japan may not be the same as in Germany, Möller's argument is also of interest for the type of rock music in question, since in the examined lyrics concepts of manhood are often accompanied by representations of violence. Notable in this respect are topics related to war and combat, serving as a means to reproduce male archetypes that stem from military cultures of certain idealised eras of the past, 
which have lost their meaning in modern society. The nexus of manhood and war becomes manifest in the contexts in which images of men come up:

The unrelenting spirit has turned into courage and is now raging on the battlefield/ The men become the wind and raise their war cry/ They tear the powerful enemy into pieces and raise the flag [...] (Brave 2003: “Junshin” 純心 [Pure Heart]).

Since war is generally interpreted as the male raison d'etre, the absence of war is conceived as a forfeiture of manhood. Peace is described as an unnatural, irrational state that contravenes the Japanese nature or yamatodamashii. In some of the examined lyrics a yearning for the days when Japan was still at war with her neighbouring countries becomes discernable:

Life is short, and in these days without combat, the birds do neither fly nor sing and the beasts don't howl/ We however, remember the day when those who died in battle went over there [...] (Yoroi 2003: "Tenka no seiei/Chirite mo ato ni kaoru hana").

Besides the topical element of war, which can be seen as a particular form of violence, representations of masculinity contain other forms of violence, which roughly speaking can be divided into two categories. The first is violence directed against persons or groups that are regarded to be of higher social status. This kind of violence, which shall be described by the term 'resurgent violence', is aimed at expanding the in-group's sphere of influence. The second form of depictions of violence, which shall be called 'repressive violence', is violence that is perceived as a means to defend the in-group's sphere of influence against groups that are deemed a threat to their sovereignty. In this context violent assaults are above all directed against members of the state apparatus. Such assaults are described as a corrective measure to politics, which are accused of being preoccupied with irrelevant discussions:

Nothing but useless information is buzzing around/ Under the guise of politics those devils are ruining our soil for future generations/ Little by little our flag is turning grey/ Now is the time to get up! Like a raging tiger/ Stir up your bloodstream and behead them!/ Restore the light of the blazing sun! Clench your fist and behead them! [...] (Raiya 2005: "Taketora no tamashii” 猛虎の魂 [The Spirit of the Raging Tiger]).

This quotation expresses the rejection of parliamentary politics that is characteristic of the examined type of rock music, which in turn is rooted in the rejection of discussion. Verbal exchange is dismissed as idle talk. Instead, the use of force is declared as the rightful way of regulating social friction. Several lyrics suggest that by the use of force the in-group will eventually turn to power. The following lyrics are representative of these visions of taking over control, which outline the in-group as a paramilitary conspiracy that is already planning a coup d'état: 
At the dawn of a new era you rebels are conspiring in the dark/ Soon power will be before your eyes, so rise up with your fists of righteousness [...] (Bull the Buffalos 1993: "Bull the Buffalos").

Repressive violence in contrast involves acts of violence aimed at repelling the social influence of certain groups or in some cases of ideas. In this connection various groups are declared as enemies and a threat to the in-group's status. Paradoxically such concepts of the enemy are constructed against already marginal groups such as immigrants, drug addicts, or homosexuals that pose as the most minor threats to the in-group's sovereignty. Since however only the powerful can be viewed as a threat, a treacherous, malicious nature is ascribed to these marginal groups:

Immigrants that loot as much as they can/ Drug dealers that sell death to the young/ Homos, junkies, and traitors/ Crush these maggots that infest our fatherland!/ Oh Japanese spirit living in our hearts! Turn into a lightning and burn everything to the ground!/ Who will save our bleeding fatherland from the arrogant devils that feast on our flesh and blood?/ Let's restore the justice, the order and the veracity of our fatherland with our own hands!/ Now justice will resurrect/ The new order shall be in our hands [...]. (Tettsui 1992: "Raimei/Lightning Strikes" 雷鳴 [Thunder/Lightning Strikes]).

It can be assumed that the reason why the groups mentioned in the above quotation are declared as enemies is not so much the physical threat they pose. Rather a certain deviance these groups represent is feared to displace what is regarded as a natural Japanese social order. Marginal groups are branded as enemies on the grounds of their mere existence, because it is contradictory to the presumption of a homogeneous society. Homosexuality comes up solely in the above quotation, where it is implicitly depicted as betrayal of an idealised bellicose masculinity. However, this reference to the topic of homosexuality should not be overestimated. Contrary to what one might expect, homophobia is not characteristic of the lyrics under consideration. Although the general emphasis on camaraderie suggests a certain homoerotic element, topics related to love and sexuality are excluded, whereas the propagated ideal of a man can be described as an asexual warrior that shows affection only towards his country.

As exemplified by the above quotation, in some of the examined lyrics claims to preside over the public order (chitsujo 秩序) are expressed. In this context the ingroup is portrayed as a vigilante group whose purpose is to restrain the excessiveness of an allegedly over-permissive society. This comes to the fore in the illiberal attitude that is expressed throughout large parts of the examined lyrics:

Does the outcry of the heroes reach your hearts?/ They allow everything to one another, but there are rules that have to be followed by all means/ Burn down the feigned freedom and peace with the flame of anger [...] (Bull the Buffalos 1993: "Chi to meiyo"). 
Generally speaking, the type of rock music under examination reproduces masculinities that rely on self-assertion through the use of force. Möller, who locates a comparable concept of masculinity in the German right-wing extremist context, notes that this kind of comprehension of manhood may seem obsolete within modern societies, but is still prevailing in right-wing extremist environments (2010: 34). Drawing on R. W. Connell's influential concept of 'hegemonic masculinity,' Fabian Virchow states that in Germany the soldierly concept of manhood has lost its hegemonic status after World War II - a fact that without a doubt can also be assumed with regard to Japan. Although marginalised within present society, this soldierly masculinity still holds a hegemonic status within the right-wing extremist male selfconcept. Virchow notes that this militaristic concept is not just an alternative script of manhood intended for their own ranks, but also functions as a counter concept to prevalent masculinities (2010: 46).

A determining factor of the construction of masculinity is a certain idea of physicalness. As Connell observes, masculinity is often regarded as something that emanates from the body, whereas behavioural patterns that are perceived as typically male are explained by alleged bodily dispositions. This is for instance reflected in the common belief that men are by nature more aggressive than women and have an innate urge to violence (Connell 2005: 45). This idea that (male) actions are predetermined by corporal drives is a fundament of this music. The irrepressible urge to fight, which already has been touched upon in the context of the term 'blood', is in some lyrics connected to depictions of masculinity. The following quotation is a representative example of this nexus of aggressiveness and manhood. Here the blood that drives its bearer to fight is described as 'manful' (óshiki 雄々しき):

The untamed spirit awakes the heart/ The manful blood is howling, telling me to fight/ The genuine, ferocious fighting instinct / My raging heart is like a wolf [...] (Tettsui 1992: "Jinrō butai/Werwolf").

In an examination of body concepts in skinheads, Möller posits that their accentuation of physicalness can be understood as a reaction to the primacy of language in post-modern societies, which is perceived as a taming of maleness (Möller 2008: 236). As indicated above in the context of the disapproval of parliamentary politics, the examined type of rock music is characterised by a rejection of verbal exchange, while violent conflict is legitimated. The notion that physical strength and the use of force overrule any verbal argument is for instance expressed as follows:

Enough with the useless discussion!-about degenerate times/ Enough with the useless discussion! - about disgrace/ Enough with the useless discussion! - the thunderclap [is the] heavenly permission/ Put them in the crosshairs!/ Force against force/ Fangs against fangs/ Put them in the crosshairs!/ Enough with the useless discussion! [...] (Yoroi 2003: "Mondō-muyō" 問答無用 [Enough With the Useless Discussion]). 
According to Möller, the above-mentioned concept of manhood is disproportioned to the requirements of modern social order for three reasons (2008: 236-237). First, this comprehension of manhood declines to accept the pluralisation of gender identities and perceives the process of social differentiation as a threat. This aspect is reflected in the examined lyrics in an implicit endorsement of clear-cut gender roles and an explicit idealisation of violent masculinity. Second, this comprehension of manhood conflicts with the growing individualisation of post-industrial societies since it is largely based on conventional ideas of community. In this respect the imaginary community that is represented in the examined lyrics through the in-group can be understood as a homo-social collective aimed at countering the isolation of the individual. The third rift between this comprehension of manhood and the requirements of modern social order lies in the refusal to subordinate bodily impulses to the rationalisations of modern lifestyles. As illustrated above, in the type of rock music under consideration an almost unrestrained force is ascribed to the (male) body.

\section{Conclusion}

The findings of the lyrical content analysis presented in the above discussion justify the conclusion that the musical phenomenon in question can indeed be defined as a Japanese form of right-wing rock. For one, the specific vocabulary contains terms such as 'yamatodamashii', the 'Japanese spirit', which imply certain myths about the origin of Japan and the Japanese people and have a long history of nationalistic and/or militaristic interpretations. Furthermore it has been shown that the term 'blood' plays a crucial role in the vocabulary of the subject of enquiry. As indicated by various quotations, the represented concept of 'nation' is largely based on the idea of blood heritage. Admittedly some of the terms of the analysed vocabulary are used with specific connotations that have to be assessed against the background of Japanese history and culture. Thus it has to be taken into account that certain semantic shifts that arise from translation are to some extent inevitable. Nevertheless several aspects of the vocabulary of the type of rock music under examination, as for instance the idea that blood is the essence of (national) pride, are symptomatic of the language of right-wing rock. Another characteristic of the linguistic properties of right-wing rock can be seen in a specific fomenting rhetoric. Arguing that the Japanese nation is about to disintegrate, some of the examined lyrics call for radical measures. In this context the two signal words 'tachiagaru' (to rise/to stand up) and 'tachimukau' (to resist/to fight against) are used. What is noteworthy is that such calls for action are often accompanied by representations of masculinity. The bellicose manhood that is idealised in large parts of the examined lyrics is defined by the social function to protect the national community and, at the same time, to advance 
the restoration of values that are imagined to have become lost. With regard to the specific vocabulary this is reflected in the frequent use of terms such as 'mamoru' (to protect/to defend), 'mamorinuku' (to protect to the end), or 'torimodosu' (to restore/to regain).

The topics comprised in the examined lyrics also substantiate the conclusion that the type of rock music in question can be defined as right-wing rock. Decidedly the most prominent topical element is war, whereas war is almost without exception portrayed in a positive way. As has been illustrated in the context of the imagery of falling cherry petals and the tokkōtai attacks, going to, as well as dying at, war is often associated with juvenile adventurism. Furthermore war is the determinant of the concept of manhood represented in the lyrics. In a manner of speaking, war is depicted as the natural environment of men, which implies a socio-biologist determinism that (Japanese) men are born to fight.

Among topics related to war, World War II holds a central position. Noticeable in this respect is that both the situation of present society and Japan's current position in global politics are explained by the defeat. The prevailing tone of the examined lyrics suggests that the spiritual and moral condition of Japanese society has deteriorated since the end of World War II. Particularly the renunciation of militarist thought is condemned as a denial of the bellicose nature of yamatodamashii. With regard to global politics, present Japanese society is accused of cowardice, whereas some bands particularly decry Japan's relation to the US as submissive behaviour.

Another characteristic that defines the phenomenon in question as right-wing rock can be seen in the approach towards Japan's wartime past. Stressing the notion of victimhood, in many cases the hardship and grief that the Japanese civil population had to endure are emphasised. At the same time the actions of those who were actively involved in the war are glorified or trivialised. In regard to this characteristic, parts of the examined lyrics rely on right-wing extremist apologetics, such as the idea that the invasion of Asia was a war of liberation, while the Pacific War is generally portrayed as defensive warfare.

Although the linguistic and topical similarities summarised above justify the term 'right-wing rock', the musical phenomenon in question cannot be compared to Western equivalents in all respects. The subject of enquiry differs significantly from what is commonly understood as right-wing rock insofar as racist thought is not a fundamental property of the lyrical contents. Only very few lyrics of the analysed sample contain dehumanisations of immigrants and other marginal groups. On the whole racist or xenophobic agitation, which is a keystone of right-wing extremist forms of music in other countries, is largely absent in the analysed form of music. Here racist tendencies are rather expressed through aggrandisements of their own racially defined collective, which becomes evident in the context the term 'blood' is used. 
With regard to the specific vocabulary and language usage, as well as the ideological contents, the examined musical phenomenon exhibits great similarities with Western right-wing extremist forms of rock music. Particularly the way the wartime past of one's own country is handled shows certain parallels to the lyrics of German right-wing rock, which may be due to the - in some respects comparable-role both countries played in World War II.

In lieu of a closing remark it shall be pointed out that Japanese right-wing rock constitutes a rewarding field for further examinations. Analyses of the reception could for instance address questions relating to the significance the audience attributes to the lyrics. In addition, transcultural comparative lyrical content analyses of right-wing rock could contribute to a deeper understanding of the right-wing extremist ideas that are emerging within modern popular cultures around the world. Diachronic comparative studies could examine rhetorical similarities of Japanese rightwing rock and the gunka 軍歌, i.e. Japanese 'military songs' that were an integral part of the propaganda of the Imperial Japanese Army (1868-1945). Several stylistic elements of the examined lyrics such as the frequently used phrase chi wa moeru 血. は燃える (the blood is burning) ${ }^{33}$ or the equation of falling cherry petals and falling soldiers are in all likelihood derived from the imagery of gunka.

33 See for example the song “Aa, kurenai no chi wa moyuru” あ〉紅の血は燃ゆる(Ah, the Crimson Blood Is Burning). Released 1944. Written by Nomura Toshio 野村俊夫 and composed by Akemoto Kyōsei 明本 京静 (Kindaichi and Anzai 1990: 274-275). 


\section{REFERENCES}

Akiakane 秋茜. “HISTORY: What is [sic] meaning of Akiakane?," 2006, http://www.akiakane. com/AKIAKANE-English/akiakane-top-e.html, accessed September 2013

Andō, Kiyoshi 安藤潔. Sakura to nihonjin nōto 桜と日本人ノート [Notes on the Flowering Cherry and the Japanese]. Tōkyō: Kōdansha, 2003

Antoni, Klaus. Shintō und die Konzeption des japanischen Nationalwesens (kokutai): Der religiöse Traditionalismus in Neuzeit und Moderne Japans. Leiden and Boston: Brill, 1998

Antoni, Klaus. "Das Reine Herz. Kokoro und die kulturelle Essenz Japans." In Sünden des Worts. Festschrift für Roland Schneider zum 65. Geburtstag, edited by Judit Árokay and Klaus Vollmer. Hamburg: Die Gesellschaft für Natur- und Völkerkunde Ostasiens [OAG], 2004, pp. 261281

Bergmann, Werner. "Ein Versuch, die extreme Rechte als soziale Bewegung zu beschreiben.” In Neonazismus und rechte Subkultur, edited by Werner Bergmann and Rainer Erb. Berlin: Metropol, 1994, pp. 83-207

Brown, Delmer M. "The Yamato Kingdom.” In The Cambridge History of Japan. Volume I: Ancient Japan, edited by John W. Hall et al. New York: Cambridge University Press, 1993, pp. 108-162

Connell, R. W. Masculinities, 2nd ed. Berkeley and Los Angeles: University of California Press, 2005

Cotter, John M. "Sounds of Hate: White Power Rock and Roll and the Neo-Nazi Skinhead Subculture." In Fascism. Volume 5: Post-War Fascisms, edited by Roger Griffin and Matthew Feldman. London and New York: Routledge, 2004, pp. 295-324

Doak, Kevin M. A History of Japanese Nationalism: Placing the People. Leiden and Boston: Brill, 2007

Döhring, Kirsten, and Renate Feldmann. "Ich weiß genau was ich will, halt nicht die Schnauze und bin still... Frauen(bilder) in rechten Subkulturen.” In RechtsRock. Bestandsaufnahme und Gegenstrategien, edited by Christian Dornbusch and Jan Raabe. Münster: Unrast, 2002, pp. 187214

Döll, Steffen. "No Heart, No Illusions: Some Remarks on Mushin." In Classical Japanese Philosophy, edited by James W. Heisig and Rein Raud. Nagoya: Nanzan Institute for Religion and Culture, 2010, pp. 58-88

Dower, John W. "Race War: American and Japanese Perceptions of the Enemy." In America Compared: American History in International Perspective. Volume 2: Since 1865, edited by Carl J. Guarneri. Boston: Houghton Mifflin, 2002, pp. 308-325

Duus, Peter. "The Greater East Asian Co-Prosperity Sphere: Dream and Reality." In Journal of Northeast Asian History, 5/1, 2008, pp. 143-154

Farin, Klaus. "Rechtsrock: Eine Bestandsaufnahme.” In PopScriptum, 5, 1995, pp. 6-15

Farin, Klaus. "In Walhalla sehen wir uns wieder..." In Die Skins: Mythos und Realität, edited by Klaus Farin. Berlin: Links, 1997, pp. 213-243

Farin, Klaus. "Reaktionäre Rebellen: Die Geschichte eine Provokation." In Rock von Rechts II: Milieus, Hintergründe und Materialien, edited by Dieter Baacke, Klaus Farin, and Jürgen Lauffer. Bielefeld: Gesellschaft für Medienpädagogik und Kommunikationskultur, 1999, pp. $12-83$

Flad, Henning. "Trotz Verbot nicht tot: Ideologieproduktion in den Songs der extremen Rechten." In RechtsRock: Bestandsaufnahme und Gegenstrategien, edited by Christian Dornbusch and Jan Raabe. Münster: Unrast, 2002, pp. 91-123 
Fogel, Joshua A. The Cultural Dimension of Sino-Japanese Relations: Essays on the Nineteenth and Twentieth Centuries. Armonk: M.E. Sharp, 1995

Frédéric, Louis. "Niitaka-yama nobore.” In Japan Encyclopedia, edited by Louis Frédéric. Cambridge MA: Belknap Press, 2002, p. 711

Hasegawa, Kenji. "In Search of a New Radical Left: The Rise and Fall of the Anpo Bund, 19551960.” In Stanford Journal of East Asian Affairs, 3/1, 2003, pp. 75-92

Häusler, Alexander. "Szene, Subkultur oder Bewegung?" In RechtsRock: Bestandsaufnahme und Gegenstrategien, edited by Christian Dornbusch and Jan Raabe. Münster: Unrast, 2002, pp. 263-286

Horikoshi, Jiro. Eagles of Mitsubishi: The Story of the Zero Fighter. Seattle: University of Washington Press, 1981

Ishinsekiseijuku: Itō Hideto 維新赤誠塾:伊藤秀人. “Toppu-pēji”トップページ [Homepage], 2013, http://www.k5.dion.ne.jp/ hide-cha/, accessed September 2013

Jansen, Marius B. The Making of Modern Japan. Cambridge MA and London: Belknap Press, 2002

Johnson, William B. The Pacific Campaign in World War II: From Pearl Harbor to Guadalcanal. Oxon and New York: Routledge, 2006

Kanazawa, Hirokazu. Black Belt Karate: The Intensive Course. Tokyo: Kodansha International, 2006

Kinard, Jeff. "Kamikazes." In World War II in the Pacific: An Encyclopedia, edited by Stanley Sandler. New York and London: Garland, 2001, pp. 497-499

Kindaichi, Haruhiko 金田一春彦, and Anzai Aiko 安西愛子. Nihon no shōka (Ge): Gakuseika-, gunka-, shūkyōka-hen 日本の唱歌 (下): 学生歌・軍歌・宗教歌篇 [Japanese Songs (Volume 3/3) Student Songs, Military Songs, and Religious Songs]. Tōkyō: Kōdansha, 1990

Krebs, Gerhard. Japan im Pazifischen Krieg: Herrschaftssystem, politische Willensbildung und Friedenssuche. Munich: Iudicium, 2010

Lee, Edwin B. "Nichiren and Nationalism: The Religious Patriotism of Tanaka Chigaku." In Monumenta Nipponica, 30/1, 1975, pp. 19-35

Linhart, Sepp. "Nationalismus und Staatenbildung im Japan des 19. Jahrhunderts." In Nationalismus: Wege der Staatenbildung in der außereuropäischen Welt, edited by Ernst Bruckmüller, Sepp Linhart, and Christian Mährdel. Vienna: Verlag für Gesellschaftskritik, 1994, pp. 129173

Lööw, Heléne. “White Power Rock 'n' Roll: A Growing Industry.” In Nation and Race: The Developing Euro-American Racist Subculture, edited by Jeffrey Kaplan and Tore Bjørgo. Boston: Northeastern University Press, 1998, pp. 126-147

Lowles, Nick. "Die Internationale des Hasses." In RechtsRock: Bestandsaufnahme und Gegenstrategien, edited by Christian Dornbusch and Jan Raabe. Münster: Unrast, 2002, pp. 233-262

Marra, Michael F. The Poetics of Motoori Norinaga: A Hermeneutical Journey. Honolulu: University of Hawai'i Press, 2007

Matsumoto, Ken'ichi 松本健一. “Ajia-shugi to Daitōa-sensō: Kita Ikki, Ōkawa Shūmei, Ishiwara Kanji, Nakano Seigō: Tōhoku Ajia ni okeru yūtopia shisō to chiiki no arikata kenkyūkai kōenkai kiroku"アジア主義と大東亜戦争 : 北一輝, 大川周明, 石原莞爾, 中野正剛：東 北アジアにおけるユートピア思想と地域の在り方研究会講演会記録 [Pan-Asianism and the Greater East Asia War: Kita Ikki, Ōkawa Shūmei, Ishiwara Kanji, Nakano Seigō: Recording of a Lecture Meeting of the Research Society on Northeast Asia Utopian Ideas]. In Tōhoku Ajia arakaruto 東北アジアアラカルト[Northeast Asia à la Carte], 18, 2007, pp. 1-58 
Möller, Kurt. "Körperpraxis und Männlichkeit bei Skinheads: Hegemonialansprüche, Marginalisierung und Rebellion." In Die soziale Konstruktion von Männlichkeit. Hegemoniale und marginalisierte Männlichkeiten in Deutschland, edited by Nina Baur and Jens Luedtke. Opladen and Farmington Hills: Barbara Budrich Verlag, 2008, pp. 223-238

Möller, Kurt. "Männlichkeitsforschung im Rahmen von Rechtsextremismusstudien. Ausgangspunkte, Ansätze, Ergebnisse und Perspektiven. ” In “Was ein rechter Mann ist....” Männlichkeiten im Rechtsextremismus, edited by Robert Claus, Esther Lehnert, and Yves Müller. Berlin: Karl Dietz Verlag, 2010, pp. 25-38

Nawrocki, Johann. Inoue Testujirō (1855-1944) und die Ideologie des Götterlandes: Eine vergleichende Studie zur politischen Theologie des modernen Japan. Hamburg: Lit Verlag, 1998

Nihon daijiten kankō-kai 日本大辞典刊行会. Nihon kokugo daijiten 日本国語大辞典. [Great Dictionary of Japanese Language], vol. 11. Tōkyō: Shōgakukan, 1974, 554, keyword "Mizusakazuki” タずーさかずき, 水杯, 水盃

Nishikawa, Yoshimitsu 西川吉光. “Nihon no senryaku-bunka to sensō” 日本の戦略文化と戦争 [Japanese Strategic Culture and Wars]. In Kokusai chiikigaku kenkyū 国際地域学研究 [International Regionology Research], 13, 2010, pp. 1-15

Ohnuki-Tierney, Emiko. Kamikaze, Cherry blossoms, and Nationalisms. Chicago and London: Chicago University Press, 2002

Parkes, Graham. "Japanese Aesthetics." The Stanford Encyclopedia of Philosophy, 2011, http://plato.stanford.edu/archives/win2011/entries/japanese-aesthetics/, accessed September 2013

Raabe, Jan. “Grenzüberschreitende Bruderschaft: Rechtsrock und Musikhandel.” In Gefährliche Liebschaften. Rechtsextremismus im kleinen Grenzverkehr. Berlin: Böll, 2008, pp. 84-92

Saaler, Sven. "Pan-Asianism in Meiji and Taishō Japan: A Preliminary Framework." In DIJ Working Paper, 4, 2002, pp. 1-35

Saaler, Sven. Politics, Memory and Public Opinion: The History Textbook Controversy and Japanese Society. Munich: Iudicium, 2005

Sabin, Roger. “'I Won't Let That Dago By': Rethinking Punk and Racism.” In Punk Rock: So What? The Cultural Legacy of Punk, edited by Roger Sabin. London: Routledge, 1999, pp. 199-218

Saitō, Shōji 斎藤正二. “Yamatodamashii” no bunka-shi“やまとだましい”の文化史 [The Cultural History of the "Japanese Spirit"]. Tōkyō: Kōdansha, 1972

Shekhovtsov, Anton. "European Far-Right Music and Its Enemies.” In Analyzing Fascist Discourse: European Fascism in Talk and Text, edited by Ruth Wodak and John E. Richardson. New York and Oxon: Routledge, 2013, pp. 277-296

Shillony, Ben-Ami. Revolt in Japan: The Young Officers and the February 26, 1936 Incident. Princeton: Princeton University Press, 1973

Sieber, Florian. "Szeneinterne Skinheadströmungen im Vergleich: Eine Analyse anhand ausgewählter Musikbeispiele.” In Sprache des Rechtsextremismus. Spezifika der Sprache rechtsextremer Publikationen und rechter Musik, edited by Georg Schuppener. Leipzig: Hamouda Wissenschaftsverlag, 2008, pp. 147-162

Takaizumi, Taku 高泉拓. “Misemono toshite no uyoku-rokkubando” 見世物としての右翼ロッ クバンド [Right-wing Rock Bands as Spectacles]. In Hokkaidō minzoku gakkai kaihō 北海道 民族学会会報 [Bulletin of the Ethnological Society of Hokkaidō], 1, 2005, pp. 53-68

Takatori, Yuki. "Remembering the War Crimes Trial: The Tokyo Trial View of History." In The Power of Memory in Modern Japan, edited by Sven Saaler and Wolfgang Schwentker. Folkestone: Global Oriental, 2008, pp. 78-95 
Tanaka, Masaaki 田中正明. “Nankin gyakusatsu” no kyokō: Matsui Taishō no nikki o megutte “南京虐殺” の虚構一松井大将の日記をめぐって [The Fiction of the “Nanking Massacre”: Based on the Diaries of General Matsui]. Tōkyō: Nippon kyōbunsha, 1984

Tanaka, Masaaki. What Really Happened in Nanking: The Refutation of a Common Myth. Tōkyō: Sekai Shuppan, 2000

Tsukuru-kai = Atarashii rekishi kyōkasho o tsukuru-kai 新しい歴史教科書をつくる会. “Shuisho" 趣意書 [Declaration of Intent]. 1997, http://www.tsukurukai.com/aboutus/syuisyo.html, accessed September 2013

Tucker, Spencer C. "Aircraft: Japanese, U.S., and British." In World War II in the Pacific: An Encyclopedia, edited by Stanley Sandler. New York and London: Garland, 2001, pp. 30-46

Uyoku-mondai kenkyū-kai 右翼問題研究会. Uyoku no chōryū: Hotei 右翼の潮流: 補訂 [The Currents of Japanese Right-wing Extremism: Expanded and Revised Edition]. Tōkyō: Tachibana shobō, 2006

Virchow, Fabian. "Tapfer, stolz, opferbereit: Überlegungen zum extrem rechten Verständnis idealer Männlichkeit.” In “Was ein rechter Mann ist....” Männlichkeiten im Rechtsextremis$m u s$, edited by Robert Claus, Esther Lehnert, and Yves Müller. Berlin: Karl Dietz Verlag, 2010, pp. 39-52

Vollmer, Klaus. "Ordnungen des Unreinen: Zur Typologie von kegare in der japanischen Kultur der Vormoderne.” In Nachrichten der Gesellschaft für Natur- und Völkerkunde Ostasiens, 179/180, 2006, pp. 197-208

von Hoyningen-Huene, Stefan. Religiosität bei rechtsextrem orientierten Jugendlichen. Münster, Hamburg, and London: Lit Verlag, 2003

Wade, Michael. "Johnny Rebel and the Cajun Roots of Right-Wing Rock." In Popular Music and Society, 30/4, 2007, pp. 493-512

Woshinsky, Oliver H. Explaining Politics: Culture, Institutions and Political Behavior. New York and Oxon: Routledge, 2008

Yamazaki, Jane W. Japanese Apologies for World War II: A Rhetorical Study, vol. 3 of Routledge Contemporary Japan Series. Abingdon and New York: Routledge, 2006

Zero Magajin ゼロマガジン [Zero Magazine]. “INTERVIEW>NAKATANI dai isshū” 弟一週 [Week One], 2011, http://zeromagazine.jp/interview/nakatani/num1/index2.html, accessed September 2013 


\section{DISCOGRAPHY}

Akiakane 秋茜. Hana wa sakuragi, hito wa bushi 花は桜木 人は武士 [What the Flowering Cherry Is among Flowers, the Warrior Is among Men]. Japan: Einstein Records, 2004 Brave. “Junshin” 純心 [Pure Heart]. On Hasshū no jinari 八州ノ地鳴り [A Rumble in the Ground in All Eight Provinces]. Japan: Hata-Age Records, 2003

Bull the Buffalos. Bull the Buffalos. USA: Vulture Rock Records, 1993

Empi 猿臂. Demo Tape デモテープ. Japan: self-release, 2000

Empi. “Boshū ni omomuku” 暮秋に赴く [Towards Late Autumn]. On Hasshū no jinari 八州ノ地 鳴り [A Rumble in the Ground in All Eight Provinces]. Japan: Hata-Age Records, 2003

Empi. Untitled. Italy: Brutus Records (= split with Billy e la sua banda), 2004

Empi. Kaze to tsuchi 風と土 [Wind and Soil]. Japan: Vital Sign Records, 2007

Garou 我狼. “Futatabi saku sakura yo” 再び咲く桜よ [Oh, Cherry Blossom Blooming Once Again]. On Hasshū no jinari 八州ノ地鳴り [A Rumble in the Ground in All Eight Provinces]. Japan: Hata-Age Records, 2003

Garou. “Garou” 我狼 [We Wolves]. On Ko-da-ma samurai spirit 谺 samurai spirit [Echo Samurai Spirit]. Italy: Brutus Records, 2005

Growl Strike. "Stop it.” On The Only Spirit, is... Unity!. Germany: S.P.E. Records, 1993; Germany: Dim Redords, 1993

Hien 飛燕. Skinheadrock-jōi Skinheadrock-攘夷 [Skinheadrock-Expell the Barbarians]. Japan: self-release, 2005

Ishinsekiseijuku 維新赤誠塾. Niitakayama nobore ニイタカヤマノボレ. Japan: self-release, 1999

Jinrai 仁籟. “Mio no kaze”澪の風 [The Wind of the Wake]. On Hasshū no jinari 八州ノ地鳴り [A Rumble in the Ground in All Eight Provinces]. Japan: Hata-Age Records, 2003

Jinrai. “Senjō no hidamari” 戦場の陽溜り [A Sunny Spell on the Battlefield]. On SamuraiSpirits- 侍-Spirits-. Japan: Einstein Records, 2004

J.U.U.M. The Far East Is Gonna Rise. Japan: self-release, 2004

J.U.U.M. Battle of Life. Japan: Restonation Records, 2005

Kaiga 嵬峨. Ishin-densho 以心伝生 [From Heart to Life]. Japan: Bronze Fist Records, 2010

Miburō 壬生狼. Skinhead Anthems. Japan: Straight Up Records/Real Life Recordings, 2001

Miburō. Kita no ōkami, nishi no tora 北の狼、西の虎 [Wolfs of the North, Tigers of the West]. Japan: Straight Up Records/Real Life Recordings (= split with Resolute Immortal Partizan), 2002

Nakatani Ryūichi 中谷隆一. Smash U.S.S.R!. Japan: Japanese Movement (= Japanese Movement Gang Tape, 1), 1988

Nakatani Ryūichi. Ajia no ōkami アジアの狼 [Wolf of Asia]. Japan: self-release, 1990a

Nakatani Ryūichi. Samurai サムライ. Japan: self-release, 1990b

Nakatani Ryūichi. Yamatodamashii no uta 大和魂の歌 [Songs of the Japanese Spirit]. Japan: selfrelease, 1990c

Raiya 雷矢. Tsumi naki hito (Ano koe ga hibiku koro, tōki sora ni namida o miru) 罪無人（あの 声が響く頃、遠き空に涙を見る） [Innocent People (When that Voice Is Echoing, I See a Teardrop in the Faraway Skies)]. Japan: H. G. Fact Records, 1997

Raiya. Owari naki tatakai 終わりなき戦い [The Never-ending Battle]. Japan: H. G. Fact Records, 2005

Resolute Immortal Partizan. Samurai Anthems. Japan: Discrete Records, 1997

Resolute Immortal Partizan. Pride \& Honour. Japan: Straight Up Records/Real Life Recordings; Germany: Cargo Records, 2000 
Resolute Immortal Partizan. Sangeshō 散華抄 [Poems of Falling Flowers]. Japan: Tag Rag Records, 2001

Resolute Immortal Partizan. Kita no ōkami, nishi no tora 北の狼、西の虎 [Wolfs of the North, Tigers of the West]. Japan: Straight Up Records/Real Life Recordings (= split with Miburō), 2002

Resshin 烈心. “Yamato, Nippon, kokoroiki” 大和 日本 心意気 [Yamato, Japan, Courage]. On Hasshū no jinari 八州ノ地鳴り [A Rumble in the Ground in All Eight Provinces]. Japan: Hata-Age Records, 2003

Sardonic Smile. Asane - Ishin kaiten 朝寝 - 維新回天 [Sleeping In - Restoration at One Blow]. Japan: self-release, 2005

Shiden 紫電. Untitled. Japan: self-release, 2004a

Shiden. "Raien" 雷炎 [Thunderbolt]. On Samurai-Spirits-侍-Spirits-. Japan: Einstein Records, $2004 b$

Shishimaru 獅風丸. Füjin 風刃 [Sharp Wind]. Japan: Vital Sign Records, 2007

Strong Style. Chi to namida e no chikai 血と涙への誓 [The Oath on Tears and Blood]. Japan: Juke Boxxx Record, 2001

Strong Style. Shishiku yōsen no kokorozashi 獅子吼鷹鸇志 [The Will of Roaring Lions and Hawks]. Japan: Juke Boxxx Record (= split with The Hawks), 2006

Tettsui 鐵桘. Samurai Thunder. USA: Vulture Rock Records (= split with Ikazuchi 雷), 1992

Tettsui. Untitled. Japan: Straight Up Records/Real Life Recordings (= split with Ouka 桜花), 2000

Tettsui. Nippon ōkami 日本狼 [Japanese Wolfs]. Japan: Straight Up Records/Real Life Recordings, 2004

The Hawks. Living on the Edge. Japan: Real Deal Records; Japan: R.O.T.B. Records, 2000

The Hawks. Tamashii no koe 魂ノ聲 [The Voice of the Spirit]. Japan: Seven Three Records, 2002

The Hawks. “Asu e” 明日 一 [Towards Tomorrow]. On Ko-da-ma samurai spirit 谺 samurai spirit [Echo Samurai Spirit]. Italy: Brutus Records, 2005a

The Hawks. "Harusora” 春空 [Springtime skies]. On Ko-da-ma samurai spirit 谺 samurai spirit [Echo Samurai Spirit]. Italy: Brutus Records, 2005b

The Hawks. Shishiku yōsen no kokorozashi 獅子吼鷹鸇志 [The Will of Roaring Lions and Hawks]. Japan: Juke Boxxx Record (= split with Strong Style), 2006

The Hawks. Nipponshugisha 日本主義者. Germany: Shout Proud Records; Japan: Goo Pa Choki Music, 2007

War Machine. "H8 - CREATIVE DESTROY." On Ko-da-ma samurai spirit 谺 samurai spirit [Echo Samurai Spirit]. Italy: Brutus Records, 2005a

War Machine. "WAR MACHINE." On Ko-da-ma samurai spirit 谺 samurai spirit [Echo Samurai Spirit]. Italy: Brutus Records, 2005b

Yoroi 鎧. Nippon no yoake 日本の夜明け [The Dawning of Japan]. Japan: Straight Up Records/Real Life Recordings, 2003

Zero Fighter. “Aoki hana” 蒼き花 [Blue Flower]. On Samurai-Spirits- 侍-Spirits-. Japan: Einstein Records, 2004 


\section{GLOSSARY OF BAND NAMES}

Akiakane 秋茜: 'Akiakane' is an alternative name for a red species of firefly that is commonly referred to as 'akatonbo'. According to the band's website, the name is derived from the popular folk song "Akatonbo". At the same time it is an allusion to a type of aircraft that originally has been used for training, but also came into operation in tokkotai attacks towards the end of the Pacific War (Akiakane 2006). The title of their album Hana wa sakuragi, hito wa bushi (What the Flowering Cherry Is among Flowers, the Warrior Is among Men) draws on an aphorism that is accredited to Ikkyū Sōjun一休宗純, a scholar of Zen Buddhism (Andō 2003: 153154).

Empi 猿臂: 'Empi' probably refers to the empi-uchi 猿臂打ち, an elbow strike in karate (Kanazawa 2006: 78).

Garou 我狼: 'Garō' (the band uses the transcription 'Garou') means 'we wolves'. A deeper meaning could not be determined.

Hien 飛燕: 'Hien', which literally means 'flying swallow', was a colloquial name for a type of fighter aircraft (Kawasaki Ki-61) that came into operation during the Pacific War (Tucker 2001: 33).

Ishinsekiseijuku 維新赤誠塾: ‘School of Restoration and Utmost Sincerity'. This sounds more like the name of a political union than a band name, since the component -juku 塾 (school) is sometimes used in the names of Japanese right-wing extremist groups.

Jinrai 仁籟: literally 'sound of benevolence', a neologism that is homophonic to jinrai 迅雷 (thunderclap). Possibly this name is an allusion to the Jinrai-butai 神雷部隊 (Corps of the Divine Thunder), an aviator volunteer unit that was deployed in the final stage of the Pacific War (Kinard 2001: 498).

Kaiga 嵬峨: 'Kaiga' means 'towering mountain'. A deeper meaning could not be determined.

Miburō 壬生狼: the Miburōshi 壬生浪士 were the forerunners of the legendary Shinsengumi 新 撰組, a special unit of the shogunate formed in the 1860s. For the syllable -rō the band replaced the Chinese character 浪 (like in rōnin 浪人 ['masterless wandering samurai']) by the Chinese character for 'wolf' 狼 (Japanese: ōkami).

Raiya 雷矢: literally 'thunderbolt'. A deeper meaning could not be determined.

Shiden 紫電: literally 'purple lightning'. Initially meaning the flash of a sword, the band name most likely refers to the colloquial name of a type of fighter aircraft (Kawanishi N1K1-J) that was used during the Pacific War (Tucker 2001: 33).

Shishimaru 獅風丸: name in phonetically used Chinese characters. A meaning could not be determined.

Tettsui 鐵桘: 'Tettsui' is the Japanese word for 'sledgehammer'. Possibly the name alludes to the tettsui-uchi 鉄槌打, a strike in karate (Kanazawa 2006: 117). As customary among parts of the Japanese right-wing faction, the band uses the old versions of the Chinese characters that were in use before the post-war script reforms.

Yoroi 鎧: 'Yoroi' means 'armour'.

Zero Fighter: Zero Fighter was the colloquial name for a type of fighting aircraft (Mitsubishi A6M type 0 ) that was one of the technically most advanced at the time of World War II (Horikoshi 1981). 


\section{GLOSSARY}

"Aa, kurenai no chi wa moyuru"

$a i$

aikoku

Ajia-Taiheiyō-sensō

Akiakane

akatonbo

Akemoto Kyōsei

Amamiya Karin

Amaterasu

Amerika

Anzai Aiko

arawashi

"Arawashi no uta"

Atarashii kamisama

Atarashii rekishi kyōkasho o tsukuru-kai

Azuma Tatsuzō
baikokudo
beikoku
chi
chigiriki
chigiru
chikai
chikau
chiru
chishio
chitsujo
chi wa moeru
chūgi
Daitōa-kyōeiken

Daitōa-sensōō
あ>紅の血は然ゆる

愛

愛国

アジア太平洋戦争

秋茜

赤とんぼ

明本京静

雨宮処燷

天照

アメリカ

安西愛子

荒鷲

荒鷲の歌

新しい神様

新しい歴史教科書を つる会

東辰三

売国奴

米国

血.

契り木

契る

誓

誓う

散る

血潮/血汐

秩序

血は燃える

忠義

大東亜共栄圈

大東覀戦争
Ah, the Crimson Blood Is Burning, title of a 'military song' released in 1944

love

patriotism

Asia-Pacific War, a term emphasising that Japan waged war both in Asia and the

Pacific area

a band from Chiba prefecture

a red species of firefly endemic to Japan

a songwriter and composer (1905-72)

a writer and political activist; former singer

of the band Ishinsekiseijuku (1975-)

the Shintō sun goddess

the United States of America

a singer, (former) politician, and musicologist (1917-)

wild eagles, term used in propaganda to

highlight daredevil pilots

a military song, written and composed in 1938 by Azuma Tatsuzō

English title: The New God, a 1999 documentary film by Tsuchiya Yutaka Japanese Society for History Textbook Reform, a controversial group that authored history textbooks that are criticised for trivialising Japan's wartime history a songwriter and composer (1900-50) traitor to the nation the United States of America blood

a flail weapon

to vow

oath

to pledge

to fall/to die (off)

bloodstream

(social/public) order

the blood is burning

loyalty

Greater East Asia Co-prosperity Sphere, a Japanese phrase indicating a federation of Asian countries under Japanese leadership Greater East Asian War, a term that was coined by the government of Japan in 1941 and implies the idea that the war is waged to liberate and unify Asia 
Daitōa-sensō kōtei-ron

datsua-nyūō

dentō

eien

eikō

eirei

eiȳu

empi-uchi

gizen

gunka

hakkō ichiu
大東带戦争肯定論

脱亜入欧
伝統
永遠
栄光
英霊

英雄

猿臂打ち

偽善

軍歌

八紘一宇

花/華

反戦

林房雄

平和

火の国

日の丸

誇り

誇る

一休宗純

Ikkyū Sōjun

ima

isagiyoku shinu

ishin

Ishinsekiseijuku

Itō Hideto
今

潔く死ぬ

維新

維新赤誠塾

伊藤秀人

偽り

偽る

神武天皇

迅雷

神雷部隊
Approval of the Greater East Asian War, a book by Hayashi Fusao

'departing from Asia, approximating Europe', a slogan that has been used from the late 19th century onwards reflecting Japan's aim to become one of the major powers and leave 'backward' Asia behind tradition

eternity

glory

heroic spirits or spirits of the war heroes, honorary term referring to the war dead, especially fallen soldiers

hero

an elbow strike in karate

hypocrisy

Japanese 'military songs', part of the propaganda of the Imperial Japanese Army (1868-1945)

eight cords under one roof, originally used in the mythological accounts of the JinmuTennō's war of conquest, the phrase was later merged with ideas of military expansionism

flower/blossom

pacifism

a writer and literary critic (1903-75)

peace

the land of fire, a metaphor for Japan

Hinomaru, the Japanese flag

pride

to be proud

a poet and scholar of Zen Buddhism (13941481)

now

dying with integrity, also used in the sense 'to die without clinging to life'

(political) restoration

a band from Tōkyō

a singer-songwriter and political activist; last remaining member of the band Ishinsekiseijuku (n.d.)

scam/deceit

to deceit/to cheat/to dupe

the alleged first Emperor of Japan (suppos-

edly 660-585BC)

thunderclap

Corps of the Divine Thunder, an aviator 


\section{jiyu}

Jūgonen-sensō

juku

kamikaze

kaze

kegare

$k i$

Kindaichi Haruhiko

kisama

Kobayashi Yoshinori

Kojiki

kokoro

kokorozashi

kokugaku
塾

神風

風

穢れ

木

金田一春彦

貴様

小林よしのり

古事記

心

志

国学 volunteer unit of the Pacific War

freedom

The 15-year War, a term that reflects the view of history that Japan's war started with the Manchurian Incident in 1931 and not as otherwise argued with the outbreak of the Second Sino-Japanese War in 1937

a school (of thought, etc.)

literally 'the divine wind', initially referring to the typhoons that were believed to have been sent by the gods to protect Japan from the Mongol invasions of 1274 and 1281, the term was also used in the Japanese propaganda of the Pacific War as a name for suicide attacks carried out by fighter aircrafts of the Japanese Imperial Navy (see also 'tokkōtai')

wind

a term describing a state of impurity wood, tree

a linguist (1913-2004)

you

a manga artist (1953-)

Record of Ancient Matters, an 8th century chronicle

heart/mind

will

national studies, a literary-philosophical school that emerged in the late 18th century. Its agenda was to abandon foreign, particularly Chinese, schools of philosophy and to refocus on the study of classical Japanese literature traitor to the nation country/state/nation pride fictional history an archaic term that describes a place of absolute bliss

守り抜く/護り抜く 守る/護る

万葉集

\section{松本健一}

舞う

名誉

目を覚める

壬生浪士 to protect to the end

to protect

Collection of the Ten Thousand Leaves, an 8 th century collection of Japanese poetry a historian and critic (1946-)

to dance

honour

to wake up

forerunners to the Shinsengumi 


Miki Rofū
minzoku
Minzoku-ha
mizusakazuki
moeru
mono no aware
moyasu
mushin
mushin no kokoro
Nakatani Ryūichi
"Nankin gyakusatsu” no
kyokō

Nihon/Nippon
Nihon daijiten kankō-kai
Nihonshoki or Nihongi
Niitakayama nobore

nise no
Nishi Amane
Nishikawa Yoshimitsu
Nomura Toshio
Okakura Tenshin or
Okakura Kakuzō
ōkami
o-mae

三木露風

民族

民族派

水盃/水杯

燃える

物の哀れ

燃やす

無心

無心の心

中谷隆一

\section{“南京虐殺”の虚構}

日本

日本国語大辞典刊行

会

\section{日本書紀/日本紀}

ニイタカヤマノボレ

偽の

西周

西川吉光

野村俊夫

岡倉天心/岡倉覚三

狼

お前

大西瀧治郎

雄々しき

プライド

浪人

斎藤正二

桜 $/$ 櫻

醒める a poet and composer (1889-1964)

people/race/ethnicity/nation

ethnic faction, umbrella term for the newer currents of Japanese right-wing extremism a sake cup of water, the ritual of drinking water from a sake cup in the event of a farewell where a reunion is uncertain to burn

an aesthetical principle; a quality that evokes a gentle feeling of wistfulness in the appreciation of things that will soon vanish to set fire to

innocent; also the Zen Buddhist concept of 'no-mind' or 'no-mindedness' that broadly speaking describes a trans-ethical state of mind that is free from discrimination innocent heart

a musician from Ōsaka, vocalist of the band Cracker Jacks and one of the first Japanese musicians to play right-wing rock (n.d.)

The Fiction of the "Nanking Massacre", a contested book by the historian Tanaka Masaaki

Japan

the editing society of the Nihon daijiten, the largest Japanese language dictionary

Chronicles of Japan, an 8th century chronicle

the code radioed by the Japanese Air Force to confirm the attack on Pearl Harbor.

'Niitakayama' was the Japanese name for Mount Yu-shan in Taiwan

fake

a philosopher and statesman (1829-97)

a political scientist (n.d.)

a songwriter (1904-66)

a philosopher (1863-1913), best known for

The Book of Tea (1906)

wolf

you

an admiral of the Imperial Japanese Navy (1891-1945)

manful/heroic

Japanese loanword for 'pride'

wandering samurai without master

an educationist (1925-2011)

cherry blossom/cherry tree

to come to one's senses 
senjō

senshi

shihai

shihaisha

Shina

shinbei-hankyō

shinjitsu
shinryaku
Shin-sayoku

Shinsengumi

Shintō

Shin-uyoku

shinzō

shishi

sokoku

sosorimaichiru

sosoru

tachiagaru

tachimukau

Taiheiȳō-sensō

tairyō gyakusatsu

Takaizumi Taku

Takeuchi Yoshimi

tamashii

tamashii naki

tamashii o moyasu

Tanaka Chigaku

Tanaka Masaaki

tatakai

tatakau

tettsui-uchi

tokkōtai

tokubetsu kōgekitai
戦場

戦士

支配

支配者

支那

親米反共

真実

侵略

新左翼

新撰組

神道

新右翼

心臓

志士

祖国

そそり舞い散る

唆る

立ち上がる

立ち向から

太平洋戦争

大量虐殺

高泉拓

竹内好

魂

魂なき

魂を燃やす

田中智学

田中正明

闘い/戦い

闘う/戦う

鉄槌打ち

特攻隊

特別攻撃隊 battlefield

warrior

power/control

those in control

a toponym for China that has had a derogatory connotation since the end of World War II

umbrella term for the 'pro-American, anticommunist' factions of Japanese right-wing extremism

truth

invasion/military aggression

The New Left, an umbrella term for the leftwing student associations that emerged after a secession from the Japanese Communist Party

a special force of the Tokugawa shogunate a Japanese religion

The New Right, coined by Japanese media as an umbrella term for the newer currents of Japanese right-wing extremism heart (the organ)

anti-Western activist of the Bakumatsu

Period (1853-68)

fatherland

to fall and rise in a dancing motion

to tower/to arise

to rise/to stand up

to resist/to fight against

The Pacific War

massacre

an anthropologist (n.d.)

a sinologist and critic (1910-77)

soul/spirit

soulless

to inflame the soul/the spirit

a scholar and preacher of Nichiren Bud-

dhism (1861-1939)

a historian (1911-2006)

fight/struggle

to fight/to struggle

a strike in karate

abbreviation of tokubetsu kōgekitai (special attack units); squadrons that carried out the suicide attacks during the Pacific War which are commonly known as 'kamikaze' full name of the tokkōtai (special attack units). See above entry 
Tōkyō saiban shikan

東京裁判史観

torimodosu
tōshi
towa
Tōyō no risō
Tsuchiya Yutaka
uyoku-dantai
Uyoku-mondai kenkyū-
kai
uyoku-rokku
waga
Wakazakura-tai

ware
warera
Yamada Kōsaku
Yamato
yamatodamashii
yami
yatsura
Zero Magajin

\author{
取り戻す \\ 闘志 \\ 永久 \\ 東洋の理想 \\ 土屋豊 \\ 右翼団体 \\ 右翼問題研究会 \\ 右翼ロック \\ 我が \\ 若桜隊
}

我

我ら/我等

山田耕作

大和

大和魂

闇

奴ら

ゼロマガジン
Tōkyō Trial view of history, a phrase used by parts of the conservative and the far-right faction implying the position that the Tōkyō Trials have introduced a biased historiography to the disadvantage of Japan to restore/to regain

will to fight eternity a book by Okukura Tenshin, English title: The Ideals of the East (1903) a filmmaker (1966-) right-wing extremist group Research Society on Right-wing Extremism

a Japanese denomination of 'right-wing rock'

my/our

Corps of the Young Cherry Blossoms, a squadron of bombers that came into operation in tokkotai attacks at the Battle of Leyte Gulf (1944)

I/myself

we

a composer and conductor (1886-1965)

an archaic name for Japan

the Japanese Spirit

darkness

them/the others

Zero Magazine, an internet music magazine 